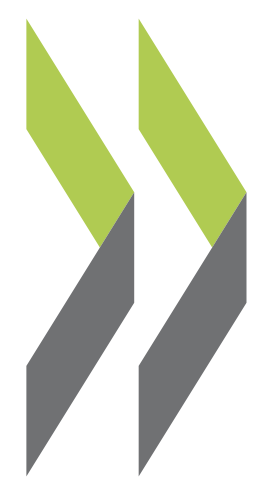

OECD Economics Department Working Papers No. 1513

Regulatory framework for the loan-based Olena Havrylchyk crowdfunding platforms 


\section{REGULATORY FRAMEWORK FOR THE LOAN-BASED CROWDFUNDING PLATFORMS}

\section{ECONOMICS DEPARTMENT WORKING PAPERS No. 1513}

\section{By Olena Havrylchyk}

OECD Working Papers should not be reported as representing the official views of the OECD or of its member countries. The opinions expressed and arguments employed are those of the author(s).

Authorised for publication by Álvaro Pereira, Director, Country Studies Branch, Economics Department.

All Economics Department Working Papers are available at www.oecd.org/eco/workingpapers.

JT03439518 
OECD Working Papers should not be reported as representing the official views of the OECD or of its member countries. The opinions expressed and arguments employed are those of the author(s).

Working Papers describe preliminary results or research in progress by the author(s) and are published to stimulate discussion on a broad range of issues on which the OECD works.

Comments on Working Papers are welcomed, and may be sent to OECD Economics Department, 2 rue André Pascal, 75775 Paris Cedex 16, France, or by e-mail to eco.contact@oecd.org.

All Economics Department Working Papers are available at www.oecd.org/eco/workingpapers.

This document and any map included herein are without prejudice to the status of or sovereignty over any territory, to the delimitation of international frontiers and boundaries and to the name of any territory, city or area.

The statistical data for Israel are supplied by and under the responsibility of the relevant Israeli authorities. The use of such data by the OECD is without prejudice to the status of the Golan Heights, East Jerusalem and Israeli settlements in the West Bank under the terms of international law.

On 3 May 2018, the OECD Council invited Lithuania to become a Member. At the time of publication the deposit of Lithuania's instrument of accession to the OECD Convention was pending and therefore Lithuania does not appear in the list of OECD Members and is not included in the OECD zone aggregates.

On 25 May 2018, the OECD Council invited Colombia to become a Member. At the time of publication the deposit of Colombia's instrument of accession to the OECD Convention was pending and therefore Colombia does not appear in the list of OECD Members and is not included in the OECD zone aggregates.

\section{(c) OECD (2018)}

You can copy, download or print OECD content for your own use, and you can include excerpts from OECD publications, databases and multimedia products in your own documents, presentations, blogs, websites and teaching materials, provided that suitable acknowledgment of OECD as source and copyright owner is given. All requests for commercial use and translation rights should be submitted to rights@oecd.org 


\section{ABSTRACT/RÉSUMÉ}

\section{Regulatory framework for the loan-based crowdfunding platforms}

In a growing number of OECD countries policymakers are designing specific regulations for lending-based crowdfunding platforms. In March 2018, as a part of its Fintech action plan, the European Commission also presented its proposal for the EU-wide passporting regime. To evaluate these new regimes, this study collects information about the regulation of lending-based crowdfunding platforms in 17 OECD countries and proposes a theoretical framework to reflect about different regulatory regimes. In this context, we explore market failures in lending-based crowdfunding and identify regulatory challenges. Although lending-based crowdfunding platforms do not technically perform risk and maturity transformation, in some countries, flexible regulation allows them to experiment with different business models to provide services of credit risk management (via risk grades, provision funds, automated lending) and liquidity provision (via secondary markets). These platforms could perform the same functions as banks in the future, but there are theoretical reasons to believe that platform-based intermediation could be more stable than banking intermediation. The success of lending-based crowdfunding platforms hinges on their ability to solve moral hazard issues and overcome significant barriers to entry related to scale and scope economies, adverse selection, as well as funding cost advantage of incumbent large banks. There are also risks related to an excessive reliance on funding of leveraged and 'too big to fail' institutional investors that are prone to runs and moral hazard problems.

JEL classification: G21, G23, G01, O33, D40

Keywords: lending-based crowdfunding, Fintech, financial regulation, barriers to entry

\section{Cadre réglementaire des plateformes de financement participatif par prêt}

Dans un nombre croissant de pays de l'OCDE, les responsables politiques sont en train d'élaborer des réglementations spécifiques aux plateformes de financement participatif par prêt. En mars 2018, dans le cadre du plan d'action FinTech, la Commission européenne a également présenté une proposition de système de passeport à l'échelle de l'UE. En vue d'évaluer ces nouveaux systèmes, les auteurs de la présente étude ont réuni des informations sur la réglementation des plateformes de financement participatif par prêt dans 17 pays de l'OCDE et proposent un cadre théorique permettant de réfléchir à différents types de réglementations. Dans ce contexte, nous avons étudié les défaillances de marché dans les activités de financement participatif par prêt et recensé les défis qui se présentent en matière de réglementation. $\mathrm{Si}$, techniquement, ces plateformes ne procèdent pas à des transformations de risques et d'échéances, dans certains pays, la souplesse de la réglementation leur permet toutefois de tester divers modèles économiques de fourniture de services de gestion du risque de crédit (au moyen de systèmes de notation des risques, de fonds de réserve, de prêts automatisés) et d'offre de liquidité (par le biais des marchés secondaires). À l'avenir, ces plateformes pourraient avoir les mêmes fonctions que les banques, mais des raisons théoriques portent à croire que leur intermédiation pourrait se révéler plus stable que l'intermédiation bancaire. Le succès de ces plateformes dépendra de leur capacité à résoudre les problèmes d'aléa moral et à surmonter plusieurs obstacles à l'entrée non négligeables liés aux économies d'échelle et de gamme, à l'antisélection, mais aussi à l'avantage dont jouissent les grandes banques classiques en termes de coûts de financement. Il existe également des risques induits par le recours excessif à des investisseurs institutionnels endettés et d'importance systémique prompts à opérer des mouvements de retraits massifs et exposés aux problèmes d'aléa moral.

Classification JEL: G21, G23, G01, O33, D40

Mots clefs: financement participatif par prêt, Fintech, régulation financière, obstacles à l'entrée 


\section{Table of contents}

\section{REGULATORY FRAMEWORK FOR THE LENDING-BASED CROWDFUNDING PLATFORMS.}

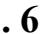

Executive summary. 6

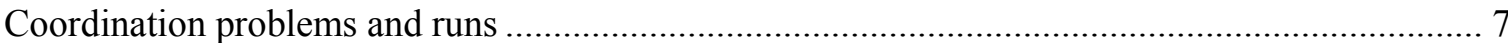

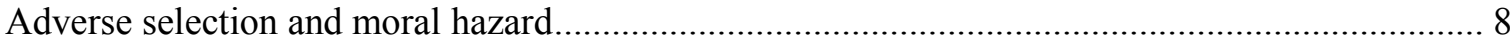

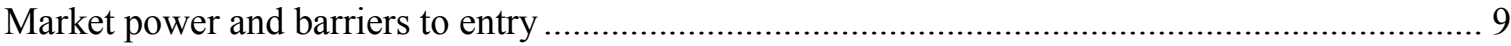

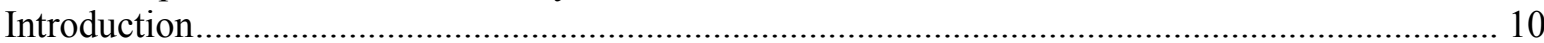

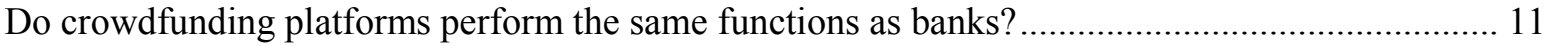

Lending-based crowdfunding platform is not a 'shadow bank' .................................................. 15

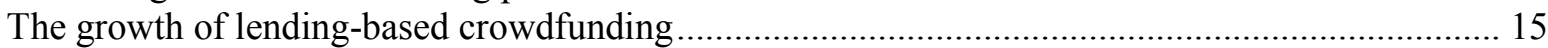

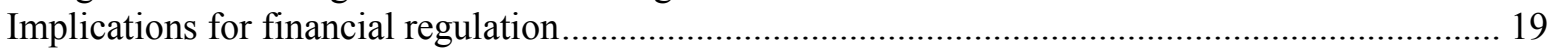

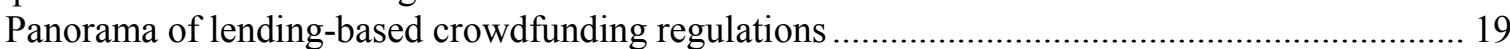

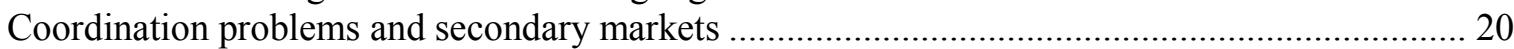

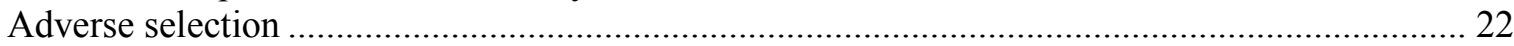

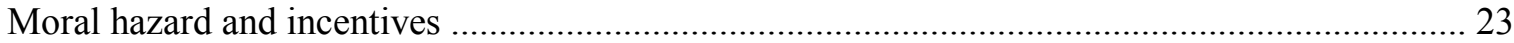

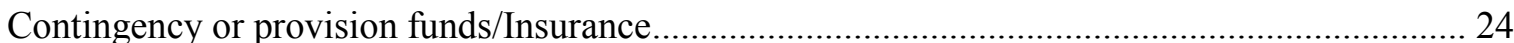

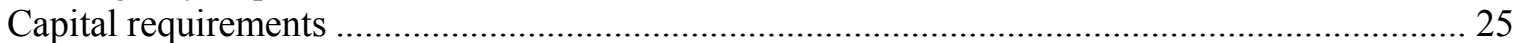

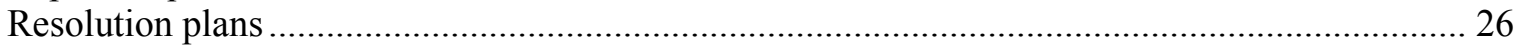

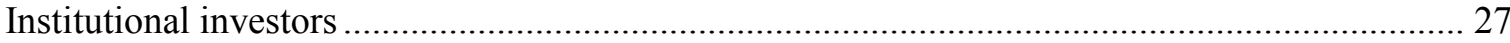

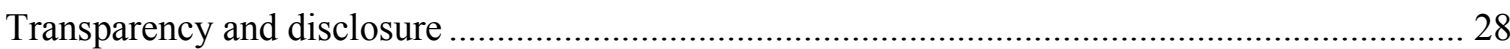

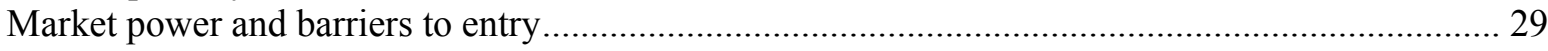

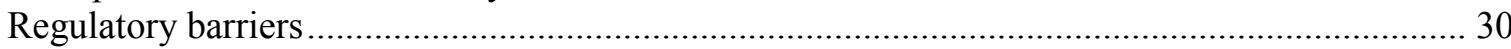

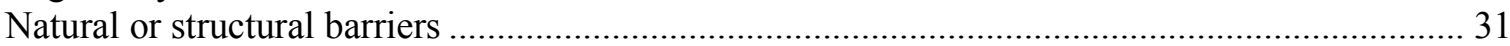

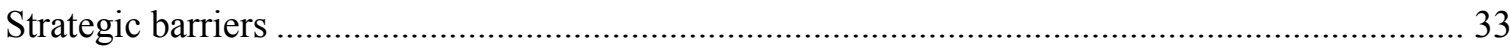

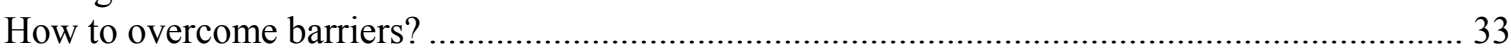

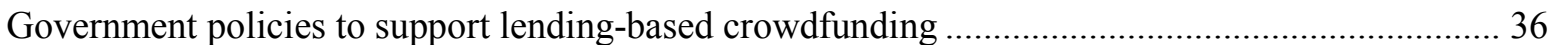

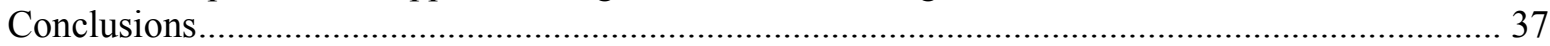

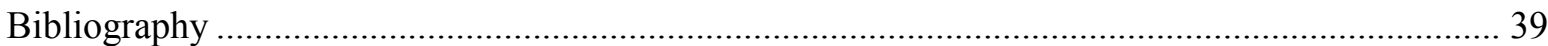

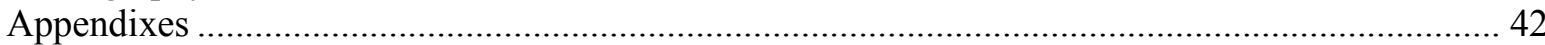

A1. REGULATION OF LENDING-BASED CROWDFUNDING PLATFORMS IN

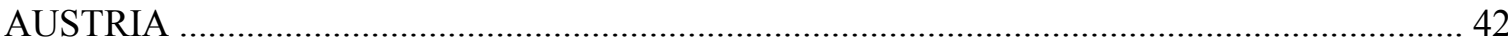

A2. REGULATION OF LENDING-BASED CROWDFUNDING PLATFORMS IN

BELGIUM

A3. REGULATION OF LENDING-BASED CROWDFUNDING PLATFORMS IN

FINLAND

A4. REGULATION OF LENDING-BASED CROWDFUNDING PLATFORMS IN FRANCE 45

A5. REGULATION OF LENDING-BASED CROWDFUNDING PLATFORMS IN

GERMANY ...................... 47

A6. REGULATION OF LENDING-BASED CROWDFUNDING PLATFORMS IN ISRAEL.. 48

A7. REGULATION OF LENDING-BASED CROWDFUNDING PLATFORMS IN MEXICO 50

A8. REGULATION OF LENDING-BASED CROWDFUNDING PLATFORMS IN

PORTUGAL

A9. REGULATION OF LENDING-BASED CROWDFUNDING PLATFORMS IN THE UK. 53

B. REGULATION OF LENDING-BASED CROWDFUNDING IN THE EUROPEAN

UNION 


\section{Tables}

Table 1. Summary of activities that are allowed by lending-based crowdfunding platforms 7

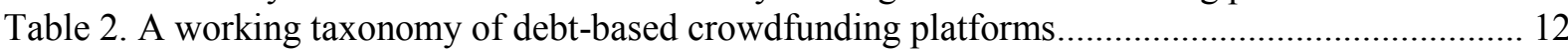

Table 3. Main functions of lending-based crowdfunding platforms and banks ................................... 14

\section{Figures}

Figure 1. Lending-based crowdfunding platforms and banks 12

Figure 2. The volume of marketplace lending/lending-based crowdfunding in the US (in \$ million).. 16 Figure 3. The volume of lending-based crowdfunding in the UK (in $£$ million) ................................... 16

Figure 4. The volume of lending-based crowdfunding in France (in $€$ million) .................................. 17

Figure 5. The volume of lending-based crowdfunding in Germany (in $€$ million) ............................... 17

Figure 6 . The volume of consumer lending-based crowdfunding in the continental Europe (in $€$ million)

Figure 7. The volume of business lending-based crowdfunding in the continental Europe (in $€$ million)

Figure 8. Business lending-based crowdfunding in the UK

Figure 9. The share of institutional investors in lending-based crowdfunding platforms 27 


\title{
REGULATORY FRAMEWORK FOR THE LENDING-BASED CROWDFUNDING PLATFORMS
}

\author{
By Olena Havrylchyk ${ }^{1}$
}

\section{Executive summary}

Enabled by new information and communication technologies, lending-based crowdfunding platforms represent a new mode of financial intermediation by connecting directly lenders and borrowers via internet platforms. While the share of loans facilitated by lending-based crowdfunding platforms is still very small, in some niche markets, platforms are becoming a real alternative to bank credit. For example, in 2016, business lending facilitated by UK crowdfunding platforms amounted to $15 \%$ of the total new loans to small businesses, compared to less than 1\% in 2012 (Zhang et al., 2017).

To review the existing regulatory practices, we have sent a questionnaire about regulation of crowdfunding to all OECD countries and have received 17 replies (Austria, Belgium, Denmark, Finland, France, Germany, Ireland, Israel, Italy, Mexico, the Netherlands, Poland, Portugal, Norway, the Slovak Republic, Sweden, the UK). While most OECD countries require lending-based crowdfunding platforms to adapt to the existing regulation, a growing number of countries have set up a new legislation to explicitly regulate this novel mode of financial intermediation. Following numerous consultations and reports, the European Commission has presented in March 2018 a proposal for the EU-wide passporting regime that concerns both lending-based and investment-based crowdfunding (EC, 2018b). Such proposal was likely motivated by the fact that the lack of the EU wide regulation was identified as an obstacle for the development of the crowdfunding market in Europe.

Although lending-based crowdfunding platforms do not technically perform risk and maturity transformation, there is an ongoing experimentation with different business models that could allow them to perform bank-like functions in the future. Firstly, many platforms allow lenders to automate their lending process by setting their lending criteria (risk, maturity, etc), which lowers their transaction costs and permits diversification. Secondly, platforms use credit scoring to assign a risk band to every borrower and effectively play the role of a delegated monitor insofar as lenders delegate to them duediligence. Thirdly, platforms provide liquidity services when they create secondary markets on which lenders can sell their loans to other investors. In 2016, Zopa, the first lendingbased crowdfunding platform, has announced that it was applying for a UK banking license. This is symbolic because Zopa has created the business model of P2P lending and its application for the banking licence signifies, on the one hand, the limits of the platform business model and, on the other hand, its similarity with the banking model.

\footnotetext{
${ }^{1}$ External consultant to the OECD. University of Paris 1 Panthéon-Sorbonne, CES, Labex ReFi. Email : olena.havrylchyk@univ-paris1.fr. The author would like to thank the OECD, and in particular Aida Caldera Sanchez, Pierre Beynet, Mamiko Yokoi-Arai, Alvaro Pereira, Caroline Roulet, and Sebastian Schich for their help in the creation and the organization of the questionnaire for this paper and for their constructive criticism. She would also like to thank all delegates of OECD countries and their respective policymakers for completing the questionnaire. Finally, she is grateful to Marianne Verdier for their numerous discussions.
} 
Table 1. Summary of activities that are allowed by lending-based crowdfunding platforms

\begin{tabular}{|c|c|c|c|c|c|c|c|c|c|c|}
\hline & AUT & BEL & FIN & FRA $^{*}$ & ISR $^{*}$ & DEU & MEX & PRT & GBR & EU \\
\hline $\begin{array}{l}\text { Max loan } \\
\text { (in mln) }\end{array}$ & $€ 1.5$ & $€ 0.3$ & No limit & $€ 1 / 2.5$ & NIS $1 / 6$ & $€ 2.5$ & $?$ & $€ 1$ & $£ 5$ & $€ 1$ \\
\hline Investment in facilitated loans & Yes & Yes & Yes & No & $\begin{array}{l}\text { No/ } \\
\text { Yes }\end{array}$ & No & Yes & No & Yes & No \\
\hline Automated lending & No & NR & NR & NR & Yes & NR & NR & No & Yes & NR \\
\hline Secondary markets & No & No & No & No/NR & $\begin{array}{r}\text { Yes/ } \\
\text { No }\end{array}$ & No & Yes & NR & Yes & Yes \\
\hline Provision funds & No & NR & No & NR & NR & NR & NR & NR & Yes & NR \\
\hline
\end{tabular}

Yes/No - if activity is allowed/not allowed; NR - if activity is not regulated or not mentioned in the law.

*Information is provided separately for two legal statuses of lending-based platforms that facilitate loan agreements and investment based platforms that facilitate debt securities.

Source: OECD Questionnaire

Regulators face a significant trade-off between encouraging innovation and preserving financial stability. The results of our questionnaire, summarised in Table 1, show that current regulatory texts do not propose any regulatory instruments, but rather define the scope of activities of crowdfunding platforms. While some regulators restrict crowdfunding platforms to simple credit intermediation, others explicitly set high maximum amount for originated loans, allow automated lending, provision funds, secondary markets and platforms' investments in loans that they facilitate. While the former approach limits shortterm risks, it also prevents platforms from experimenting with business models and eventually competing with banks in the future. In this context, the recent EC proposal appears to be more on the conservative side since it does not mention automated lending, limits the maximum loan amount to 1 million Euros, explicitly forbids platforms' investment in loans and limits the responsibility of platforms in the organization of the secondary markets (called bulletin boards).

To structure the discussion about regulation, we explore three types of market failures in the financial system that need to be addressed by the regulators: (1) coordination problems and runs (2) moral hazard and adverse selection (3) market power and barriers to entry. This will allow to reflect about the need to regulate the lending-based crowdfunding and highlight challenges that need to be addressed.

\section{Coordination problems and runs}

Secondary markets are offered by many large lending-based crowdfunding platforms. They are a useful feature for providing liquidity to investors and could be essential for scalingup of platforms. Theoretically, there is a good reason to believe that platforms with secondary markets would not be subject to coordination problems and self-fulfilling runs in the same way as banks are. The direct link between lenders and borrowers ensures that lenders' strategy (to run or not to run) does not depend on the strategy of other lenders, but only on the solvency of borrowers in their loan portfolio. Nevertheless, secondary markets might become illiquid and misprice traded securities. Also, it would be misleading for platforms to promise lenders maturity transformation (i.e. their investment can be always liquidated). Currently, secondary markets are forbidden in many countries and in some cases the regulatory approach is not clear (see Table 1). In particular, the EU proposal explicitly states that platforms cannot put in place a trading system but, instead, proposes a bulletin board that allows investors to interact directly with each other to buy and sell loan 
agreements or transferable securities. Importantly, such buying and selling activity on crowdfunding platforms is at the client's own discretion and responsibility.

Regulatory challenges: To allow or not the functioning of secondary markets? If secondary markets are allowed, how to ensure that insider trading and market abuse are forbidden? How to ensure that platforms do not guarantee the transformation of maturity to lenders and communicate this clearly?

\section{Adverse selection and moral hazard}

Retail lenders face severe adverse selection problems when they have to decide to whom to lend. This problem is particularly acute because most regulators set a low limit on the maximum size of loans (see Table 1), thus, allowing lending only to small businesses, which tend to be riskier and more opaque. To mitigate this problem of adverse selection, lenders delegate due-diligence to crowdfunding platforms, but they still bear most of the losses. Hence, addressing problems related to informational asymmetries should be at the heart of the financial regulation and it is important to ensure that platforms have good risk management systems in place. Many platforms are likely to experiment with new methods of credit scoring that rely on big data and machine learning. While these techniques are promising, they are still untested. Importantly, due diligence and scoring models are currently not supervised.

Since lenders bear all credit losses, alignment of incentives between platforms and lenders is important. To signal risk retention, several platforms invest in loans that they facilitate, while others use their own capital to create provision funds that absorb first losses. Indeed, if platforms do not retain risk of loans that they facilitate, their business model could resemble an "originate and distribute" model of the securitization process that was pointed out as one of the major causes of the global financial crisis due to the loosening credit standards. However, in the EU proposal, platforms are explicitly forbidden to invest in loans that they facilitate in several countries (see Table 1). This rule is motivated by the potential conflicts of interest that could lead to "cherry picking" the best loans. Such concerns are legitimate and if platforms invest in loans, they should invest in all loans.

Finally, if platforms become systemically important in the future, it is important to ensure the possibility of an orderly resolution, i.e. the continuation of loan repayments so that lenders do not lose money solely as a result of the platform's failure. It is important because the existence of financial institutions that are too big or too interconnected to fail increases the likelihood of state bail-outs, and, hence, intensifies moral hazard concerns. While we have yet to experience a failure of a large platform, the direct connection between lenders and borrowers gives us reason to think that it is easier to design an orderly resolution of a platform than that of a bank. Since all lenders bear their own losses, it is comparable to a bail-in mechanism.

Regulatory challenges: How to ensure that platforms have good risk management systems in place without constraining innovation in scoring models? How to regulate the alignment of incentives between platforms and lenders? If platforms are allowed to invest in loans that they facilitate, how to ensure that there is no cherry-picking? How to design minimum capital requirements that ensure platforms' solvency and align incentives between lenders and platforms? How to ensure a smooth resolution of platforms in the case of the failure?

Most platforms allow investment of sophisticated institutional lenders, such as insurance companies, banks, hedge funds, investment groups or family offices. While a co-financing 
model between retail and institutional investors provides an important guarantee to borrowers that their loans will be funded, an excessive reliance on the institutional money might pose significant risks to the financial stability in the long run. Most institutional lenders are leveraged and 'too big to fail' institutions that are prone to runs and moral hazard problems. In this case, all the advantages of the lending-based crowdfunding business model (e.g. less prone to runs, easier resolution, no leverage) are lost.

Regulatory challenges: How to ensure fair treatment of retail and institutional investors? How to avoid the interconnectedness of lending-based crowdfunding platforms with leveraged and 'too big to fail' institutions?

\section{Market power and barriers to entry}

Even if well-designed lending-based crowdfunding platforms might represent a better business model of financial intermediation than banking, they are facing numerous barriers to entry (regulatory, structural and strategic). They are entering a market dominated by large banks and, due to high switching costs, platforms are forced to pursue the market expansion strategy towards risky borrowers that are underserved by the incumbent banks. This has worked during the post-crisis period, when banks needed to deleverage and have cut their loan supply to creditworthy borrowers. However, if entrants serve only borrowers that are rejected by banks, they risk to have higher default rates and lose servicing fees. Hence, the long-term viability of the crowdfunding business model is likely to require a direct competition with banks for good borrowers. This is complicated by the fact that incumbent banks have a distinct informational advantage over lending-based crowdfunding platforms. Due to long-term banking relationships, they possess granular data on their borrowers that allow them to model default risk. Scale and scope economies, inherent in the financial intermediation, also represent a significant barrier to entry. Finally, an explicit and implicit government guarantees imply a funding cost advantage, allowing large banks to provide credit at a lower interest rate than crowdfunding platforms, all other things being equal.

Regulatory challenges: How to level the playing field between platforms and banks? How to ensure that new entrants do not face adverse selection problems with respect to banks' borrowers? Should policymakers facilitate switching to new technologies and with what instruments? How to ensure that policies towards incumbent banks (such as explicit and implicit guarantees that result in lower funding costs) do not distort the level playing field between banks and crowdfunding platforms?

In many countries authorities design policies that support lending-based crowdfunding. In particular, development banks lend via crowdfunding platforms and invest in them, which provides a valuable signal that the crowdfunding business model is viable. Also, authorities in several countries have adapted their taxation policies to lending-based crowdfunding. Notably, lenders are able to subtract crowdfunding losses from their revenues in the calculation of the tax base. In some countries, the authorities have introduced tax benefits for the crowdfunding activity that are similar to other financial products. While such government support could be an essential tool in helping crowdfunding platforms to overcome high barriers to entry, it would be worth considering accompanying it with impact assessments. 


\section{Introduction}

Enabled by new information and communication technologies, lending-based crowdfunding platforms represent a new mode of financial intermediation by connecting directly lenders and borrowers via internet platforms. When first platforms appeared in the UK and the US, they were called peer-to-peer (P2P) consumer (or business) lending platforms. As the role of institutional investment increased, the term 'marketplace lending' has become the norm in the US' ${ }^{2}$. The European Commission (EC) uses the term 'lendingbased crowdfunding platforms', the term which is also used in this paper, while the UK Financial Conduct Authority (FCA) prefers the term 'loan-based crowdfunding platforms'.

"Investment-based" crowdfunding platforms are different from "lending-based" crowdfunding platform in the sense that funders invest in unlisted shares or debt securities issued by businesses. However, from the economist's perspective, as long as crowdfunding platforms offer secondary markets, the difference between a loan agreement and a debt security is blurred. This is why the analysis in this paper applies to all crowdfunding platforms that facilitate debt, notwithstanding the legal nature of the underlying financial instrument (loan agreement, notes, minibonds, debentures or other debt securities). ${ }^{3}$

All these platforms are a part of the wider Fintech movement, which is often viewed as an opportunity of making financial intermediation more transparent, efficient and stable. The share of loans facilitated by lending-based crowdfunding platforms is still very small and even in countries with the most developed crowdfunding markets, only around $1 \%$ of total loans are facilitated by platforms. In some countries' niche markets, however, platforms are becoming a real alternative to bank credit and their importance is growing. For example, in 2016, business lending facilitated by UK crowdfunding platforms amounted to $15 \%$ of the total new loans to small businesses by banks, compared to less than 1\% in 2012 (Zhang et al., 2017).

This paper reviews the existing regulatory practices of 17 countries that replied to an OECD questionnaire about regulation of lending-based crowdfunding platforms (Austria, Belgium, Denmark, Finland, France, Germany, Ireland, Israel, Italy, Mexico, the Netherlands, Poland, Portugal, Norway, the Slovak Republic Sweden, the UK). A growing number of countries have set up a specific legislation to explicitly regulate lending-based crowdfunding platforms. Following numerous consultations and reports (EC, 2015, 2016, 2017), the European Commission has presented in March 2018 a proposal for the EU-wide passporting regime that concerns both lending-based and investment-based crowdfunding (EC, 2018b). This proposal is part of the EU Fintech action plan (EC, 2018a) and was likely motivated by the fact that the lack of the EU wide regulation was identified as an obstacle for the development of the cross-border crowdfunding market in Europe (EC, 2017).

\footnotetext{
${ }^{2}$ When discussing the US market, the term marketplace lending platforms is used because in the US the word crowdfunding applies only to equity, reward and donation crowdfunding platforms and might be misunderstood. When referring to the UK platforms, the term of P2P is occasionally used.

${ }^{3}$ This study excludes equity crowdfunding platforms that connect directly investors and start-ups and are seen as an alternative to the venture capital or seed capital. While this form of crowdfunding is becoming an important source of start-up financing, its analysis requires a different theoretical framework. It also excludes research on reward and donation crowdfunding that is alternative to traditional charity and patronage activities. Finally, this paper does not cover balance sheet lenders, because the business model is close to a shadow bank and, hence, their regulation is covered by the literature on the shadow banking.
} 
This paper explores these new regulatory regimes of lending-based crowdfunding platforms and identifies regulatory challenges. Lending-based crowdfunding platforms are often presented as an alternative to traditional banks and, therefore, it is first assessed whether these new actors could perform the same functions as banks. Although lendingbased crowdfunding platforms do not technically transform risk and maturity, there is an ongoing experimentation with different business models (automated lending, provision funds, secondary markets, etc.) that allows platforms to manage risk, play the role of delegated monitor and provide liquidity services (Havrylchyk and Verdier, 2018). Hence, they could perform functions similar to banks.

To identify regulatory challenges, the discussion is structured about three types of market failures that need to be addressed by the regulator: (1) coordination problems and runs (2) moral hazard and adverse selection (3) market power and barriers to entry (Freixas and Rochet, 2008). Careful analysis of these market failures provides justification for the financial regulation. Importantly, different business models of lending-based crowdfunding platforms could lead to different market failures. Since platforms are entering a market dominated by large incumbent banks, careful attention is devoted to barriers to entry (regulatory, structural and strategic), platforms' strategies to overcome them as well as government support policies.

This paper contributes to the earlier work about regulation of lending-based crowdfunding platforms undertaken by different European institutions (ESMA, 2014, EBA, 2015, EC, $2015,2016,2017)$. In particular, this paper is closely related to the report of the EC (2016) that surveys new regulatory regimes in the EU member states that were specifically designed for lending-based crowdfunding platforms. The contribution of this paper is twofold. First, it extends the survey to cover regulatory practices in OECD countries. Second, and more importantly, it specifically addresses the question of platforms' business models and how regulation could define the scope of their activities. It is important because the design of lending-based crowdfunding platforms impacts their ability to perform banklike functions. More generally, earlier studies assume that crowdfunding platforms fill a niche by serving credit-constrained borrowers excluded from the banking sector. In contrast, our study takes a more forward-looking approach grounded in the financial intermediation theory to understand whether lending-based crowdfunding platforms could compete with banks in the future and how regulation could influence this scenario.

\section{Do crowdfunding platforms perform the same functions as banks? ${ }^{4}$}

Table 2 presents the classification of lending-based crowdfunding platforms that follows the taxonomy developed by the Cambridge Center for the Alternative Finance. Lendingbased crowdfunding platforms offer credit to consumers (e.g. Zopa and Ratesetter in the UK, Prosper and Lending Club in the US, Bondora in Estonia) and to SMEs (e.g. Funding Circle in the UK, Geldvoorelkaar in the Netherlands, Lendix and Unilend in France). Some platforms specialize in property-secured lending to property developers (e.g. LendInvest in the UK), while others offer a possibility to SMEs to sell their invoices to investors (e.g. MarketInvoice in the UK, Investly in Estonia) or invest in sustainable development (e.g. Lendosphere in France, Abundance in the UK).

Table 3 summarizes the main differences between business models of lending-based crowdfunding platforms and banks. Both banks and lending-based crowdfunding platforms

\footnotetext{
${ }^{4}$ This section draws on the work of Havrylchyk and Verdier (2018).
} 
perform the brokerage role by connecting funders (depositors in the case of banks and lenders in the case of platforms) and borrowers (individuals and businesses). While bank depositors do not have much visibility of how their money is used, crowdfunding platforms remove the need for balance sheet intermediation and give the possibility to retail investors to choose to whom they would like to lend (Figure 1). Indeed, many lenders are attracted to this form of intermediation because it allows them to invest in local businesses as well as socially and environmentally responsible projects. This decision can be made by analyzing credit score (assigned by the platform to every project), interest rate, industry, location and the objective of the project.

Figure 1. Lending-based crowdfunding platforms and banks

Bank

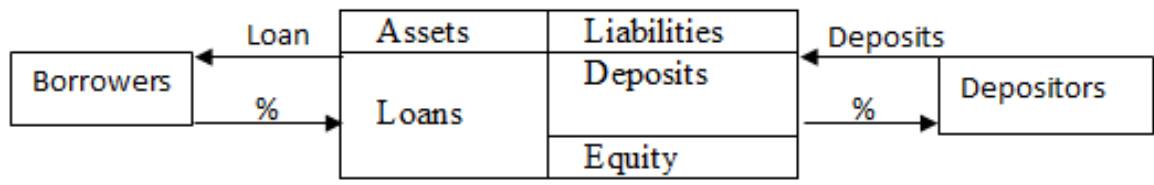

\section{Loan-based crowdfunding platform platform}

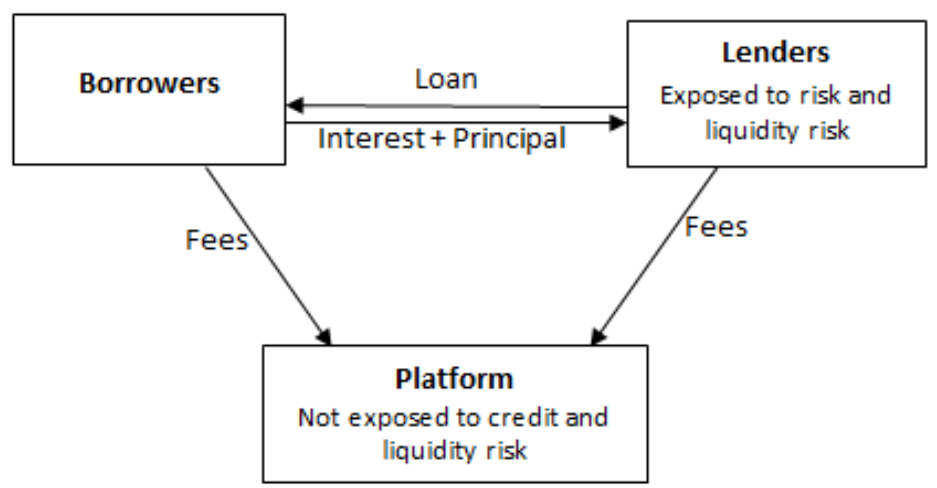

Table 2. A working taxonomy of debt-based crowdfunding platforms

\begin{tabular}{|c|c|}
\hline Crowdfunding business model & Definition \\
\hline $\begin{array}{l}\text { Marketplace/P2P Consumer } \\
\text { Lending }\end{array}$ & $\begin{array}{l}\text { Individuals or institutional funders provide a loan to a } \\
\text { consumer borrower. }\end{array}$ \\
\hline $\begin{array}{l}\text { Marketplace/P2P Business } \\
\text { Lending }\end{array}$ & Individuals or institutional funders provide a loan to a business borrower. \\
\hline Invoice Trading & $\begin{array}{l}\text { Individuals or institutional funders purchase invoices or } \\
\text { receivable notes from a business at a discount. }\end{array}$ \\
\hline $\begin{array}{l}\text { Marketplace/P2P Property } \\
\text { Lending }\end{array}$ & $\begin{array}{l}\text { Individuals or institutional funders provide a loan secured against a property to a } \\
\text { consumer or business borrower. }\end{array}$ \\
\hline Debt-based Securities & $\begin{array}{l}\text { Individuals or institutional funders purchase debt-based securities, typically a bond or } \\
\text { debenture at a fixed interest rate. }\end{array}$ \\
\hline Mini-Bonds & $\begin{array}{l}\text { Individuals or institutions purchase securities from companies in the form of an unsecured } \\
\text { retail bonds. }\end{array}$ \\
\hline
\end{tabular}

Note: Debt-based crowdfunding applies to lending-based crowdfunding platforms as well as investment-based crowdfunding platforms that facilitate the issue of minibonds and other debt securities.

Source: Cambridge Center for the Alternative Finance. 
Most mature platforms offer the function of the automated lending (also called auto-bid or auto-selection), where a lender can set lending criteria, such as risk band, maturity, interest rate, maximum investment in one loan, industry, location, etc. Several online platforms pool loans in different portfolios that differ with respect to risk or even go a step further and pool all loans together by offering a lender an opportunity to spread their funds across the entire loan book. The minimum sum that can be invested in each business is small on

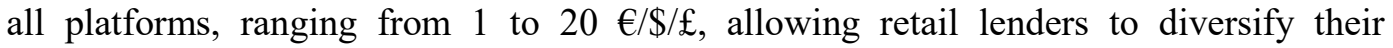
investment. The survey of the Cambridge Center for the Alternative Finance shows that $77 \%$ of P2P Consumer Lenders and 49\% of P2P Business lenders in Europe make use of auto-bid or auto-selection function for their platform lending (Ziegler et al., 2018). The figure is expected to go up as the crowdfunding goes mainstream and attracts less sophisticated investors. The availability of the automated investment decreases lenders' transaction costs and allows them to diversify their loan portfolio, which are the two essential functions of financial intermediaries.

Another important function of financial intermediaries is the alleviation of problems related to informational asymmetries. Depositors delegate the job of monitoring borrowers to a bank and this results in risk transformation. ${ }^{5}$ In the case of standard crowdfunding platforms, platforms do not hold loans on their balance sheets and lenders bear all credit risks. Hence, theoretically they need to monitor both borrowers and platforms, which should increase monitoring costs. In practice, the majority of platforms sets interest rates on loans that depend on borrower's credit score and loan maturity, and survey evidence shows that almost $70 \%$ of lenders in the UK rely on the due-diligence conducted by platforms (Zhang et al., 2017). Numerous observers in the UK believe that even though crowdfunding platforms do not perform risk transformation, they are similar to banks because lenders rely on platforms' due diligence in a manner not fundamentally different from bank deposits (FCA, 2016).

Successful development of platform intermediation requires the alignment of incentives of platforms and lenders. Platforms attempt to signal the quality of their due-diligence and credit risk assessment in two important ways. First, some platforms (or platform owners) invest in loans that they originate to signal that their incentives are aligned with those of lenders. (e.g. Lendix). Second, platforms create contingency or provision funds that allow smoothing returns (e.g. Ratesetter, Prexem, Assetz Capital). These funds are financed either by a risk-weighted contribution paid by borrowers or lenders and/or by the capital provided by the platform itself. Importantly, even if some provision funds could have a $100 \%$ track record (e.g. Ratesetter), these platforms do not represent a guaranteed-return business model and if losses are greater than the provision fund, they will be borne by lenders. The existence of a provision fund could be an important strategy, because as long as realized returns are equal to projected returns, lenders do not need to audit the platform and can delegate the monitoring of borrowers to platforms, which is in line with the model of Diamond (1984). Even in the absence of provision funds, platforms could signal the quality of their scoring models by publishing projected returns (taking into account projected bad debt), which would allow lenders to compare them with realized returns.

If a borrower defaults on their loans, platforms promise to make their best efforts on behalf of lenders to recover the unpaid balance from delinquent borrowers. This involves structuring a new payment plan, selling collateral, contacting external collection agencies and taking other appropriate actions to recover a loan. Sometimes, platforms charge fees

\footnotetext{
${ }^{5}$ The model of a bank that plays the role of a delegated monitor is proposed by Diamond (1984).
} 
for this activity. When platforms have access to credit registries and bureaus, they also report delinquent borrowers to them.

Another difference between banks and lending-based crowdfunding platforms is the fact that platforms do not guarantee liquidity transformation. However, a growing number of platforms organize secondary markets allowing lenders to liquidate their investment by selling their loans to other lenders. In more mature platforms, buyers and sellers can post their prices online and the deal is settled more or less automatically if the demand and supply meet. Selling a loan could be done with a premium or a discount, depending on the market supply and demand. Defaulted loans are sometimes excluded from the sale. A sale fee is charged by some platforms. Unlike banks, withdrawing funds from lending-based crowdfunding platforms is not guaranteed and is done only as long as there are interested buyers. While one could imagine that liquid secondary markets could help lenders to sell their loans without losses during normal times, this is not guaranteed if secondary markets are illiquid during crisis times.

Unlike banks that earn their profits from the interest spread, platforms earn their profits from fees. Most platforms charge an origination fee (in \% of the loan) at the time of loan origination and a servicing fee (in $\%$ of capital due) that is paid during loan reimbursement. If a loan defaults, $\mathrm{P} 2 \mathrm{P}$ lending platforms do not perceive servicing fees, which impact their profits. In addition, some P2P lending platforms charge borrowers a collection fee in percent of the amount recovered in the case of no litigation, or in percent of hourly attorneys' fees if litigation is involved. Given that standard crowdfunding platforms do not themselves invest in their loans, the fee structure that is skewed to the origination fee creates a principal-agent problem as platforms have a short-run incentive to maximize loan volume, which could loosen their credit standards (Davis and Murphy, 2016).

Finally, modern banks create money every time when they extend a credit. Such monetary creation is important because around $90 \%$ of money in the modern economy is created by private banks. Lending-based crowdfunding platforms do not create money; they only intermediate money between lenders and borrowers. This implies that in the platform-based financial intermediation, innovative ways of monetary creation should be envisaged. Otherwise, economic growth could suffer from too little credit.

Table 3. Main functions of lending-based crowdfunding platforms and banks

\begin{tabular}{|c|c|c|}
\hline & Lending-based crowdfunding platforms & Bank \\
\hline Brokerage function & $\begin{array}{l}\text { Direct lending via a platform. Removes the need for } \\
\text { balance sheet intermediation. } \\
\text { Orderly resolution is possible via a built-in 'bail-in' } \\
\text { mechanism }\end{array}$ & $\begin{array}{l}\text { Intermediated lending. Bank is a } \\
\text { black box. } \\
\text { Orderly resolution is difficult. }\end{array}$ \\
\hline $\begin{array}{l}\text { Bank as delegated } \\
\text { monitor }\end{array}$ & $\begin{array}{l}\text { Possible duplication of monitoring costs if lenders have } \\
\text { to monitors borrowers and platforms. } \\
\text { Platforms publish credit scores, but they do not invest in } \\
\text { loans (No skin in the game) ? moral hazard problems. } \\
\text { Platforms may signal the reliability of information by } \\
\text { investing in loans. Monitoring costs go down if returns } \\
\text { are smoothed via provision fund. }\end{array}$ & $\begin{array}{l}\text { Banks act as delegated monitors due } \\
\text { to the existence of the risk-free } \\
\text { deposit contract. } \\
\text { Capital adequacy rules ensure that } \\
\text { banks absorb losses, which signals } \\
\text { the reliability of information that they } \\
\text { produce. }\end{array}$ \\
\hline Risk transformation & $\begin{array}{l}\text { No, losses are born by lenders } \\
\text { (unless returns are smoothed via provision fund) }\end{array}$ & Yes \\
\hline $\begin{array}{l}\text { Liquidity provision and } \\
\text { maturity transformation }\end{array}$ & $\begin{array}{l}\text { No (unless secondary market). Hence, not subject to } \\
\text { bank runs } \\
\text { If there is no liquidity on the secondary markets, this is } \\
\text { similar to the suspension of deposit convertibility }\end{array}$ & $\begin{array}{l}\text { Yes, which makes them very fragile } \\
\text { to self-fulfilling bank runs without } \\
\text { government guarantees }\end{array}$ \\
\hline Monetary creation & No & $\begin{array}{l}\text { Yes. When bank extends a loan, it } \\
\text { creates a deposit. }\end{array}$ \\
\hline
\end{tabular}




\section{Lending-based crowdfunding platform is not a 'shadow bank'}

A standard lending-based crowdfunding platform cannot be considered as a "shadow bank $^{6}$. Since lenders bear all risks, funding does not have deposit-like characteristics and platforms do not perform risk transformation. Platforms, even those with secondary markets, do not guarantee maturity transformation and/or liquidity transformation and, hence, are not subject to self-fulfilling bank runs. Finally, platforms do not use direct or indirect leverage. However, attention should be paid to hybrid business models that could promise deposit-like characteristics and liquidity transformation.

As a caveat, it is important to distinguish between lending-based crowdfunding platforms and other fintech start-ups that perform credit intermediation, in particular balance sheet lenders (e.g. Kabbage, OnDeck, SoFi). As the name suggests, balance sheet lenders keep originated loans on their own balance sheets and, hence, they retain all credit risk. While their capital ratios are currently multiple times higher than those of banks, these intermediaries perform risk transformation and rely on leverage and, hence, have a business model that is similar to banks, i.e. they are shadow banks (Buchak et al., 2017). Fintech balance sheet lenders are excluded from our analysis, because internet has not fundamentally transformed their business model.

\section{The growth of lending-based crowdfunding}

The first P2P lending platform, Zopa, was launched in the UK in 2006. Shortly afterwards, two P2P lending platforms, Prosper and Lending Club, were founded in the US. These two countries remain the leaders of lending-based crowdfunding among OECD countries. In the US, consumer lending amounted to $\$ 21.1$ billion in 2016, compared to $\$ 7.6$ billion in 2014, while business and property lending is less developed (Figure 2). In the UK, all lending-based crowdfunding amounted to $£ 4.1$ billion, almost equally divided between consumer, business and property lending (Figure 3). In continental Europe, lending-based crowdfunding started developing much later and in 2016, in France, the continental leader in terms of total lending-based crowdfunding (consumer and business loans, invoice financing, mini-bonds and other debt securities), only $€ 0.31$ billion of debt financing was facilitated by platforms (Figure 4). Germany is the second largest market for lending-based crowdfunding, with $£ 0.22$ billion of loans (Figure 5). Figures 6 and 7 report the amount of consumer and business lending in the continental Europe, where Netherlands and Germany lead in business and consumer lending, respectively.

Even in countries with the most rapid development of lending-based crowdfunding platforms, the share of loans facilitated by platforms is less than $1 \%$ of total loans originated by banks. It is better to consider the importance of crowdfunding in niche markets, such as small business lending or consumer lending. For example, in 2017, business lending facilitated by the UK crowdfunding platforms amounted to $15 \%$ of total new loans to small businesses by banks, compared to less than $1 \%$ in 2012 (Figure 8). Hence, for the UK small businesses, P2P lending platforms are becoming a real alternative to bank credit and their importance is growing. Unfortunately, it is difficult to measure the importance of

\footnotetext{
${ }^{6}$ The October 2011 Financial Stability Board report defines shadow banking system as a "the system of credit intermediation that involves entities and activities outside the regular banking system". The European Comission (2012) has complemented this definition with the following characteristics of a shadow bank: (1) accepting funding with deposit-like characteristics; (2) performing maturity and/or liquidity transformation; (3) undergoing credit risk transfer; and, (4) using direct or indirect financial leverage.
} 
crowdfunding in other niche markets, because reliable data on new loans for small businesses or consumers originated by banks is scarce. Specifically, since banks hold loans on their balance sheet, official statistics capture only outstanding loans, while crowdfunding platforms report data on new loans.

Figure 2. The volume of marketplace lending/lending-based crowdfunding in the US (in \$ million)

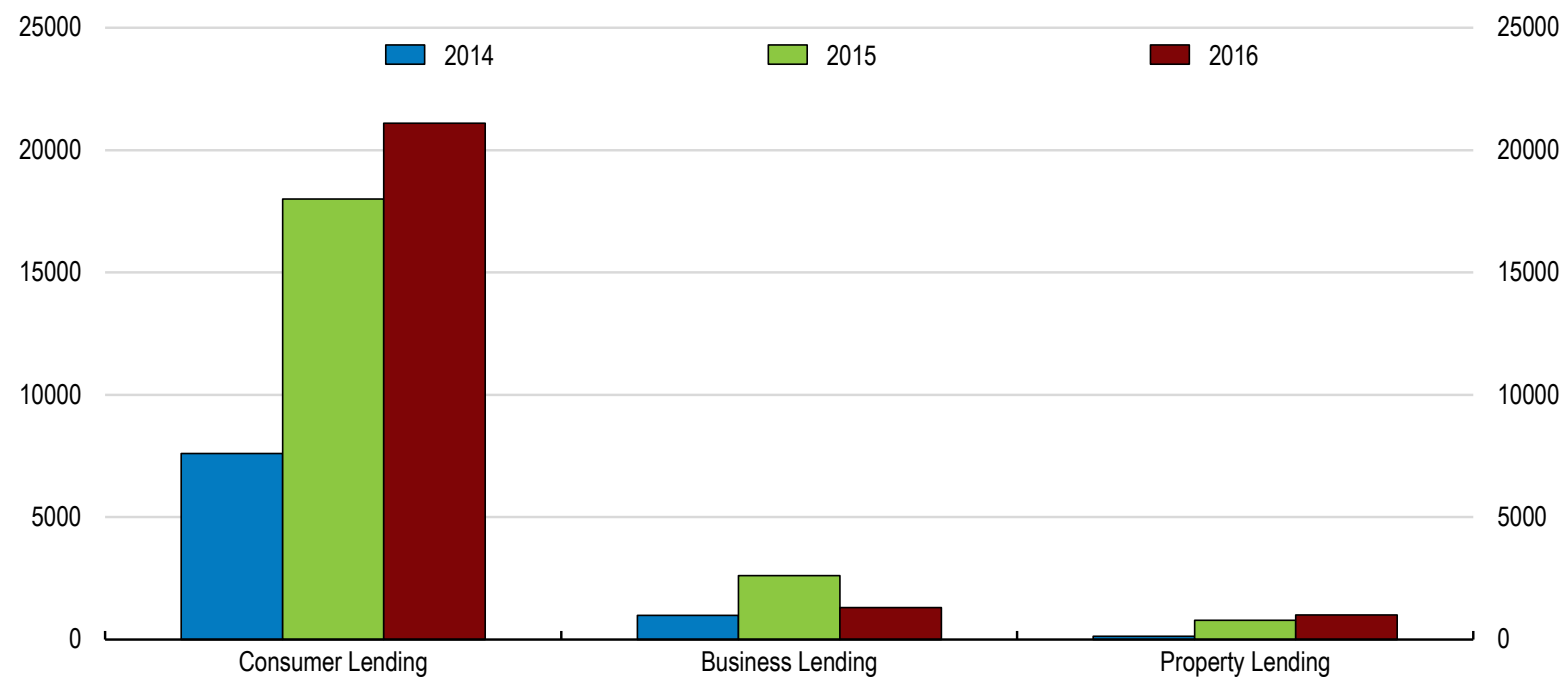

Source: Cambridge Center for the Alternative Finance.

Figure 3. The volume of lending-based crowdfunding in the UK (in $£$ million)

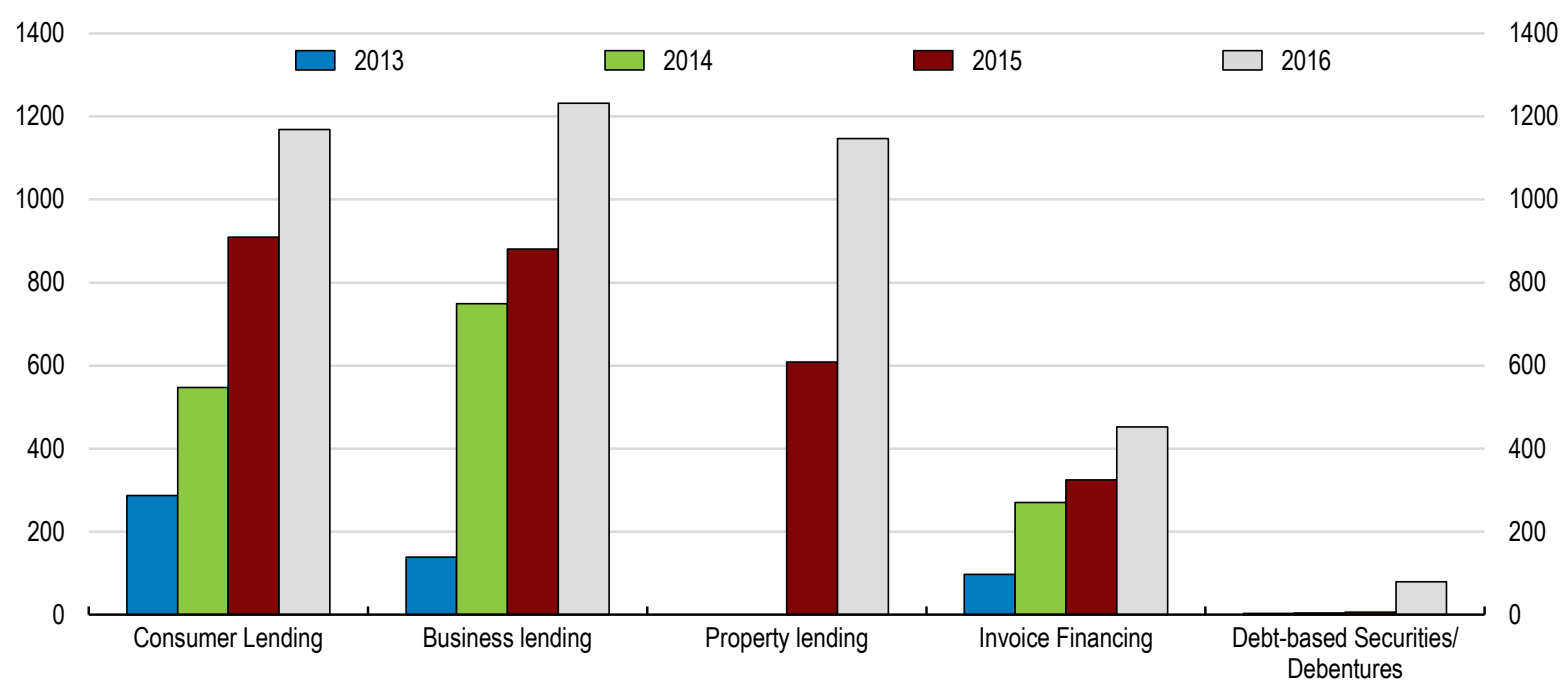

Source: Cambridge Center for the Alternative Finance. 
Figure 4. The volume of lending-based crowdfunding in France (in $€$ million)

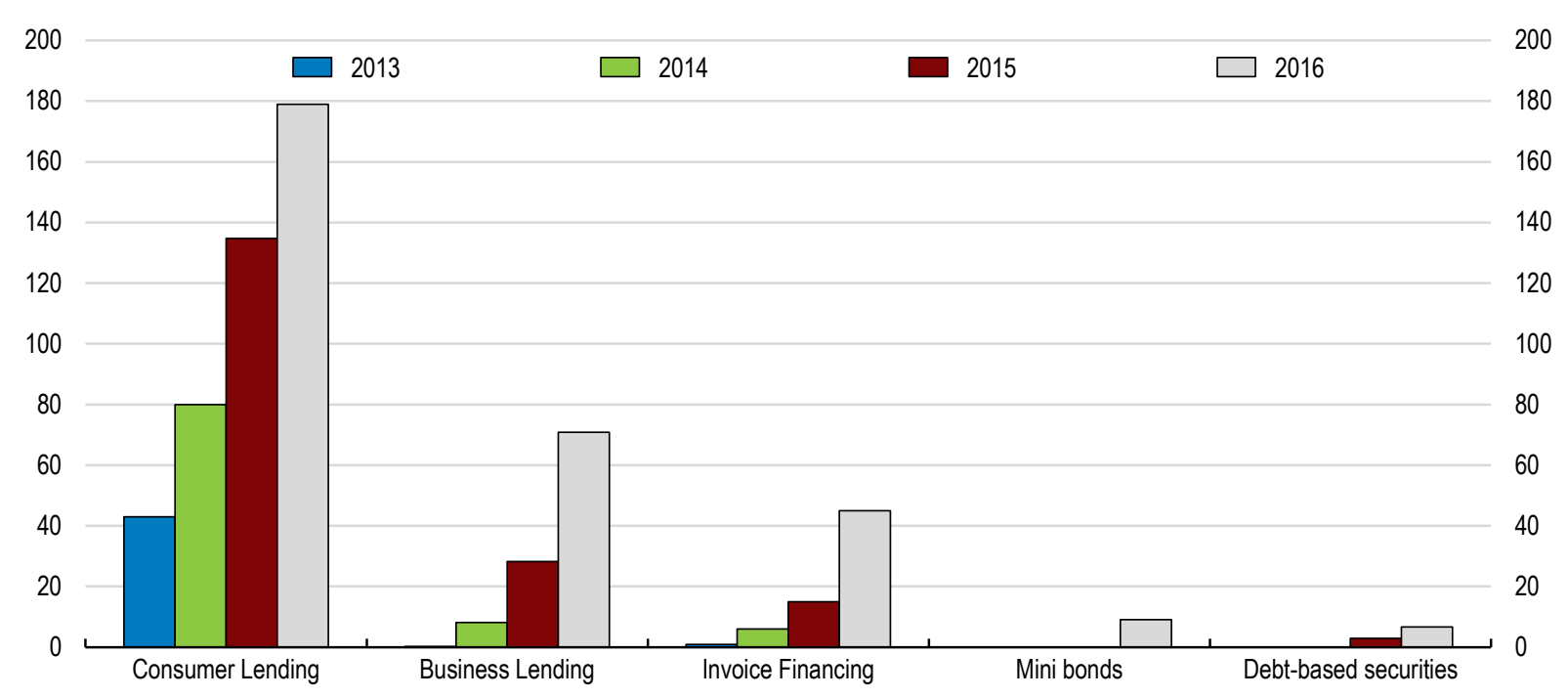

Source: Cambridge Center for the Alternative Finance.

Figure 5. The volume of lending-based crowdfunding in Germany (in $€$ million)

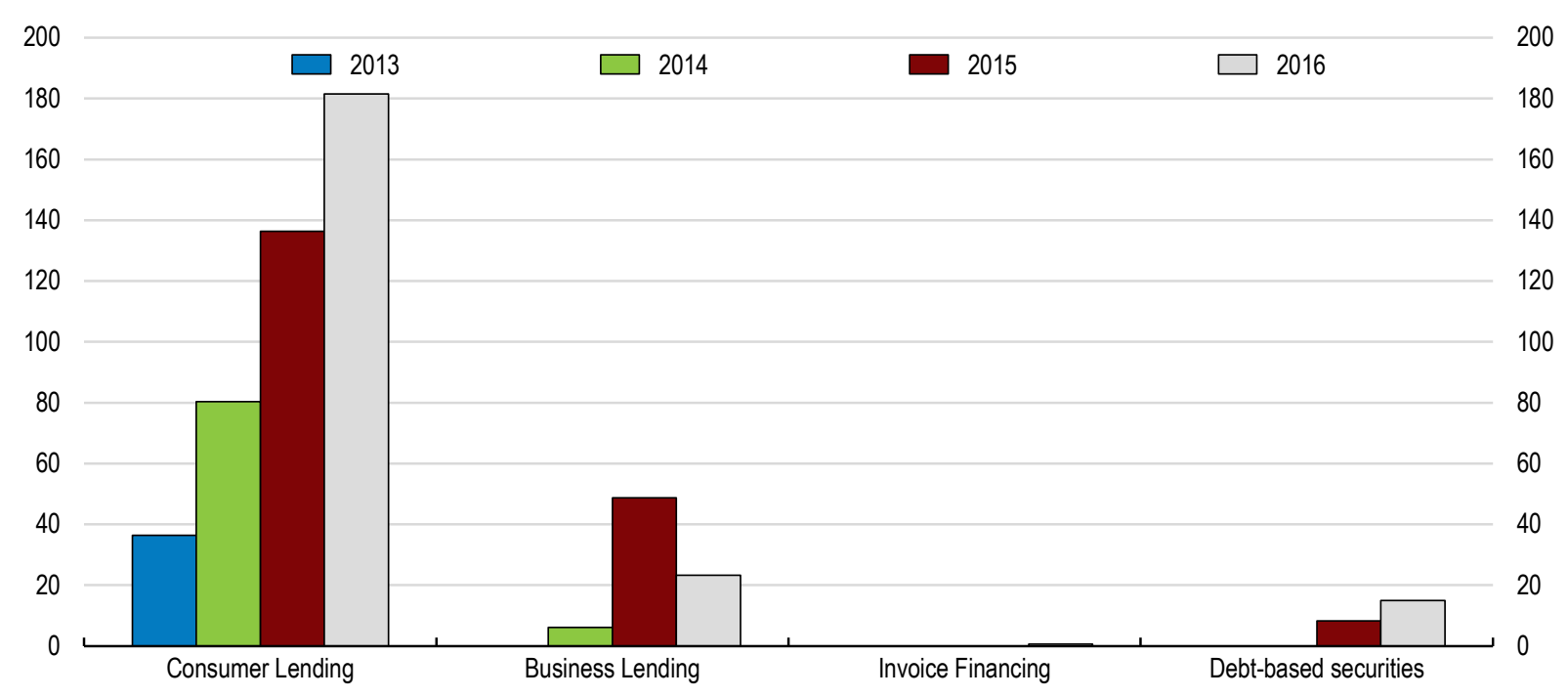

Source: Cambridge Center for the Alternative Finance. 
Figure 6. The volume of consumer lending-based crowdfunding in the continental Europe (in $€$ million)

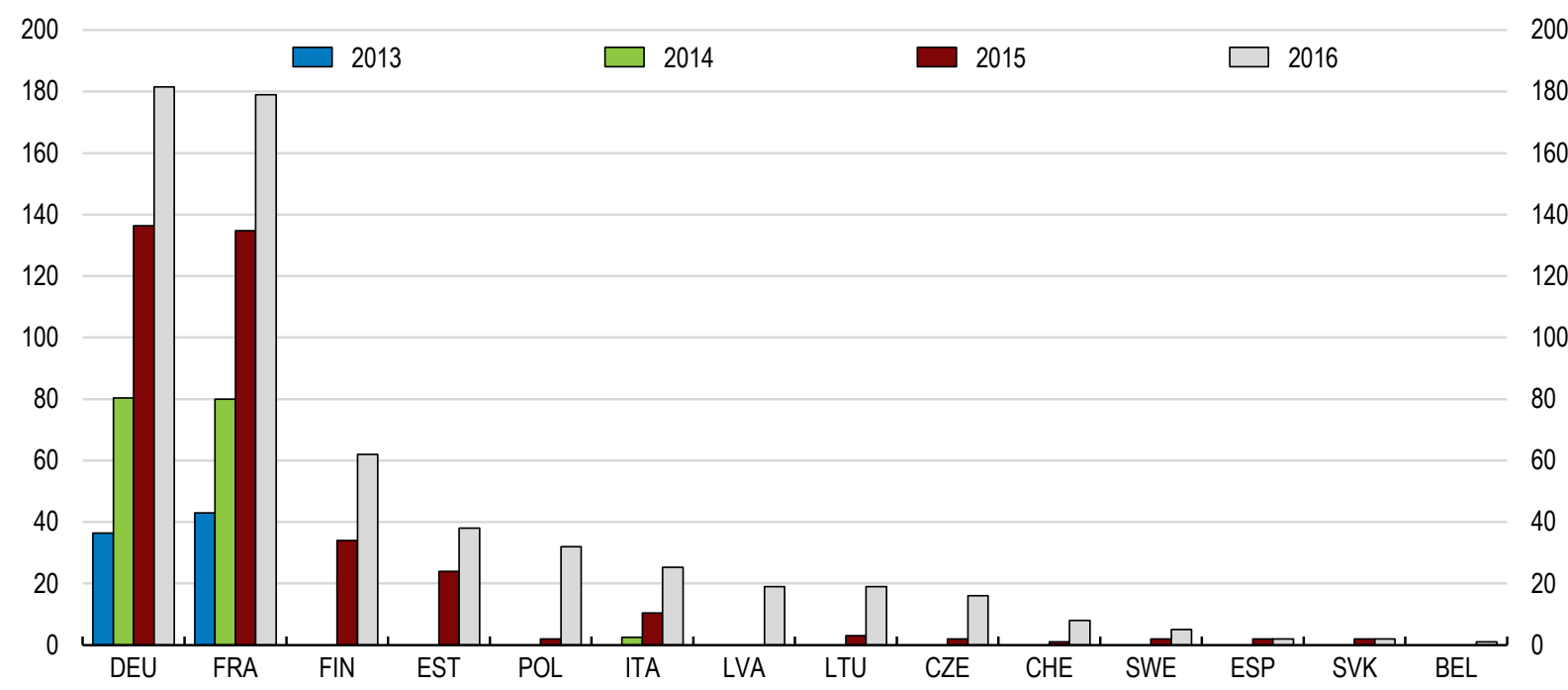

Source: Cambridge Center for the Alternative Finance.

Figure 7. The volume of business lending-based crowdfunding in the continental Europe (in $€$ million)

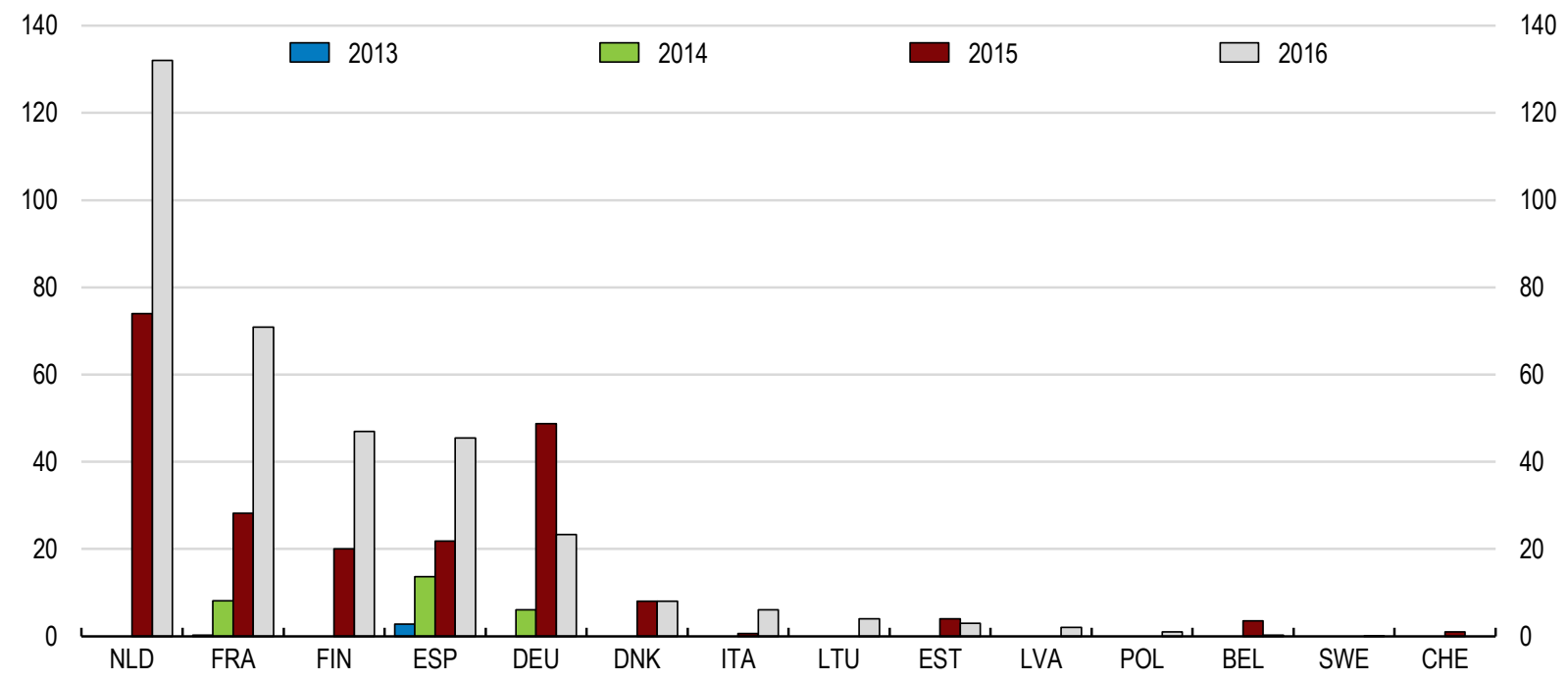

Source: Cambridge Center for the Alternative Finance. 
Figure 8. Business lending-based crowdfunding in the UK

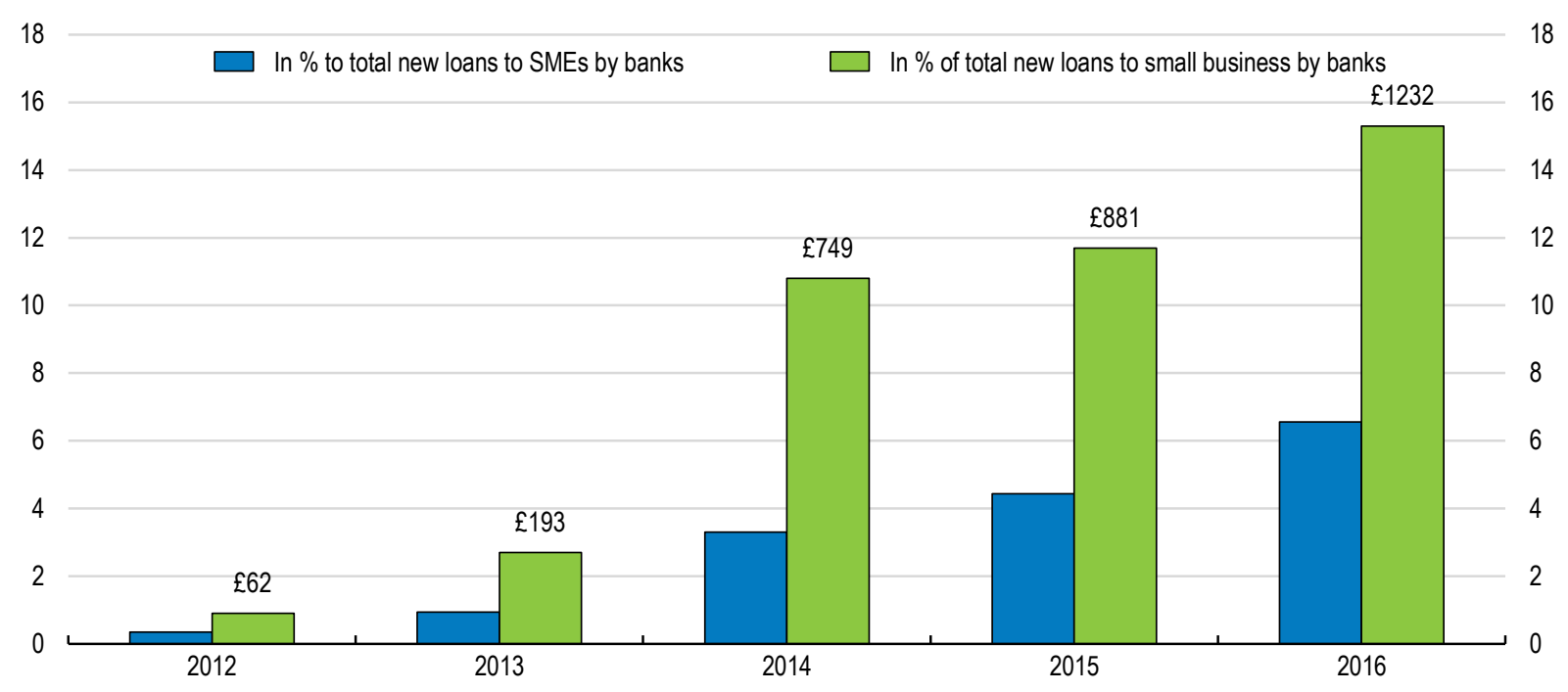

Source: Cambridge Center for the Alternative Finance

\section{Implications for financial regulation}

In light of the earlier discussion, this section draws a theoretical framework that would allow policymakers to think about the regulation of this new type of financial intermediaries. This helps assess existing regulatory practices in the OECD countries as well as the EU proposal for the regulation of crowdfunding (EC, 2018).

\section{Panorama of lending-based crowdfunding regulations}

To do a review of the existing regulatory practices in the OECD countries, a questionnaire was sent to regulators of all OECD countries and 17 countries have replied (Austria, Belgium, Denmark, Finland, France ${ }^{7}$, Germany, Ireland, Israel, Italy, Mexico, the Netherlands, Norway, Poland, Portugal, the Slovak Republic, Sweden, the UK). Appendix A summarized new regulatory regimes that have been explicitly designed for lending-based crowdfunding platforms or for investment-based crowdfunding platforms that allow debt securities. The details of the EU proposal are summarized in Appendix B.

Different countries have chosen different regulatory approaches towards lending-based crowdfunding platforms. A number of countries have set-up a specific legislation to explicitly regulate lending-based crowdfunding platforms (France, the UK and Israel). Other countries have introduced crowdfunding regulation that either applies to both lending-based and investment-based crowdfunding or appears to not distinguish between the two business models (Austria, Belgium, Finland, Mexico, Portugal). The EU proposal falls into the latter category. Germany has introduced only investment-based crowdfunding regulation, but it allows debt securities and, hence, it is included in this analysis. In contrast,

${ }^{7}$ As shown in Appendix A, France and Israel have introduced two separate regimes for lendingbased and investment-based crowdfunding platforms. Since several investment-based platforms intermediate minibonds and other debt securities, our analysis applies to them as well. 
Italy has set up the investment-based crowdfunding regulation that refers only to equity securities and, hence, is excluded from this analysis ${ }^{8}$.

In countries that do not have any lending-based crowdfunding regulation, platforms adapt to the existing regulation of securities trading, banking or payment institutions. In the Netherlands, consumer-to-business platforms have to get an individual release from the Dutch Financial Markets Authority to perform brokerage activities, while consumer-toconsumer platforms require a creditor license. In Sweden and Denmark, lending-based platforms operate as payment institutions, while in Norway - they are registered as loan intermediaries. In France, where banking monopoly still exists for consumer credit, one consumer-to-consumer platform has obtained a credit institution license. In Estonia, consumer-to-consumer lending platforms fall under the regulation of consumer lending by the Financial Supervision Authority, while consumer-to-business lending is not regulated. In Ireland, platforms operate without any legal status of the financial intermediary.

Financial regulation is designed to address three types of market failures in the financial system: (1) Coordination problems and runs (2) Moral hazard and adverse selection (3) Market power (Freixas and Rochet, 2008). As it was discussed earlier, lending-based crowdfunding platforms perform the brokerage role of the financial intermediation, but unlike banks they do not transform maturity and risk. These differences are important because they imply that a well-designed lending-based platform intermediation might have several advantages over banking intermediation, as will be discussed in what follows.

\section{Coordination problems and secondary markets}

Crowdfunding platforms are not subject to inefficient 'bank runs' because there are no coordination problems between lenders. In contrast, in a fractional banking system, even solvent banks are fragile to self-fulfilling panics because if a depositor thinks that other depositors are going to withdraw money, the only rational decision for this depositor is to withdraw money before other depositors. This first-come, first-served rule is important not only in causing individual run, but also in causing contagion and systemic banking panics? Deposit insurance and lender of last resort are modern solutions to the problem of selffulfilling bank runs (Schich, 2014).

In the case of platforms, the first-come, first-served rule does not apply because lenders and borrowers are connected directly. Lenders' return depends on the solvency of the borrowers in their loan portfolio and not on the decision of other lenders to keep their loans or sell them on the secondary markets. It is true that if all other lenders decided to sell their loans, market liquidity would dry up and a lender would need to wait till loan maturity to recuperate his/her money. However, the investment return of this lender would not change and would be even higher if we assume non-zero fees on the secondary market. Hence, if a lender does not experience a liquidity shock and he/she thinks that borrowers are solvent,

\footnotetext{
${ }^{8}$ Italy has been the first EU member country that took advantage of the exemption of Directive 2004/39/EC ("MiFID I") and introduced in 2013 a national regulatory framework for equity based crowdfunding. Since 2013, 20 platform managers (for equity crowdfunding) have been authorized by Consob (the Italian stock exchange authority), which is the competent authority for equity crowdfunding in Italy. Platform managers can also operate under the scope of MiFID II if they are authorized as investment firms or banks. As of now only two of them have chosen this regime.

${ }^{9}$ Self-fulfilling bank runs are modeled by Diamond and Dybvig (1983). There are three solutions to this problem: narrow banking, deposit insurance and convertibility of deposits; equity financing of a bank (Freixas and Rochet, 2008).
} 
the only rational decision is to keep the money invested via the platform. From this discussion follows that crowdfunding platforms do not require government deposit insurance to reach this unique equilibrium. Secondary markets on platforms could function similarly to the limited convertibility of deposits (Freixas and Rochet, 2008).

While secondary markets are a useful mechanism for providing liquidity to investors, they are forbidden in several countries and the regulatory approach is not clear in most countries (see more details in Table 1 or the Appendices A and B). In Israel, secondary markets are allowed for smaller loans, but would require a stock exchange management license for larger loans and debt securities. In contrast, in France, secondary markets "are not foreseen" for lending-based crowdfunding platforms (for loans up to $1 \mathrm{mln}$ Euros) but "are not excluded" for investment-based crowdfunding platforms (for debt securities up to $2.5 \mathrm{mln}$ Euros) and even "foreseen" for minibonds that will be traded on the blockchain (as it is explained later). In this context of regulatory uncertainty, none of the French platforms offers secondary markets because they are not sure whether they have the right to do it. Several authorities have noted that platforms would need to obtain an additional license to organize secondary market (e.g. MiFID license in several EU countries). In Portugal, secondary markets are not forbidden but legislation provides no details about their organization. The EU proposal introduces a concept of a bulletin board that allows investors to interact directly with each other to buy and sell loan agreements or transferable securities which were originally crowdfunded on their platforms. However, the crowdfunding platform should inform their clients that they do not operate a trading system and that such buying and selling activity on their platforms is at the client's own discretion and responsibility.

There appears to be two reasons for the lack of consensus about whether to allow or not secondary markets. First, some regulators are concerned that secondary markets transform lending-based crowdfunding into the securitization, which has been identified as a key cause of the global financial crisis. However, the problem with the securitization is related to the loose underwriting standards of the 'originate and distribute model' and a 'shadow bank' nature of the special purpose vehicles, not the existence of the secondary markets. Second, there are concerns about insider trading and market abuse (when loans are traded with discounts and premiums), which call for the appropriate regulation of platforms' secondary market. For example, to avoid insider trading, one could envisage a regulation that prevents the lender to choose which loans are liquidated, so that the decision is only made when a lender needs liquidity and cannot use its private information.

Currently, functioning secondary markets exist in the US and the UK. While the lack of data on order books prevents researchers to investigate their functioning, there is evidence that the use of secondary markets is rather limited, with annual transactions amounting to less than one-fifth of the size of the loan book on the largest UK platforms (Zopa, Ratesetter, Funding Circle) (Oxera, 2016). Investors appear to use secondary markets to exit their investment in the event of the liquidity shock and not as a speculative tool. Such usage is reinforced by fees that are charged by most platforms and by forbidding to sell defaulted loans on some platforms.

In France, the ordonnance from December 2017 has introduced the concept of the blockchain (dispositif d'enregistrement électronique partagé) that will allow the registration and trading of different financial instruments, including minibonds issued by French investment-based crowdfunding platforms. This legislation provides a framework for experimentation with a new technology in the organization of secondary markets. 
Development of secondary markets might be a necessary condition for scaling up of lending-based crowdfunding because lenders seek liquid assets. However, several platforms have begun to offer investors to take out their money after a certain notice period or initial term, which introduces a worrying maturity mismatch (FCA, 2016). Many observers in the UK feel that platforms that promise investors instant access to their money would be making unclear, unfair or misleading promotions (FCA, 2016). Hence, platforms should issue risk warnings to explain to investors that even in the presence of secondary markets, unlike banks, they do not guarantee contractual liquidity, but establish conditions for market liquidity. In other words, they do not perform maturity transformation. Moreover, platforms should have the mechanisms to detect, prevent and respond to any potential market manipulation. Eventually, for secondary markets to function properly, a more comprehensive regulation suitable for the trading of unlisted securities should be developed.

\section{Regulatory challenge: How to ensure that platforms issue risk warnings to explain to investors they do not perform maturity transformation? How to prohibit insider trading and market abuse to allow secondary markets to function correctly?}

\section{Adverse selection}

Retail investors that rely on crowdfunding platforms face important adverse selection problems because they do not know the quality of borrowers. This problem is particularly acute because most regulators set a low limit on the maximum size of loans (e.g. EUR 1 $\mathrm{mln}$ in the EU proposal), hence constraining lending-based crowdfunding to small businesses that are inherently risky and opaque (see more details about maximum size of loans in Table 1 or the Appendices A and B). To mitigate adverse selection problem, lenders rely on the due diligence and credit risk assessment of platforms that, similar to credit rating agencies, provide risk grades to potential borrowers. Although this is a form of financial advice to potential lenders (Davis and Murphy, 2016), platforms do not bear the responsibility for the quality of their advice and argue that their risk grades are provided for the information purpose only and do not constitute investment advice.

The current regulation of lending-based crowdfunding platforms obliges platforms to disclose main features of loans and characteristics of borrowers. However, the correctness of this information is not always verified. Moreover, platforms' due-diligence and credit risk assessment are not supervised. To be clear, the supervisor faces a trade-off between innovation and financial stability. Several lending-based crowdfunding platforms are seeking to replace relationship lenders and traditional credit scoring with innovative algorithms based on big data and machine learning. Still in its infancy, such analysis attempts to predict creditworthiness by analysing buying habits, memberships, reading proclivities, lifestyle choices, trustworthiness and satisfaction scores on eBay, Amazon and TripAdvisor, information from Facebook, LinkedIn, etc. These models are untested and the evaluation of their prediction power is a difficult task, but it is important to experiment with these innovative scoring methodologies.

Internet provides an opportunity to harness the 'wisdom of crowds' (i.e. soft information collected and processed by individual lenders) that could complement hard data to solve information asymmetries (see literature surveys by Morse, 2016; and Belleflamme et al., 2015; Havrylchyk and Verdier, 2018). An extensive research on this topic documents that social ties, such as endorsement and bids on friends' applications or friends' creditworthiness, provide an informative signal for lenders and raises their returns (Freedman and Jin, 2014; Everett, 2010, Lin, Prabhala, and Viswanathan, 2013, Lu, Gu, 
Ye, and Sheng, 2012). Nevertheless, it also shows that such information could be easily manipulated as friends learn to bid on each other's applications to increases their chances of being funded (Freedman and Jin, 2014). Also, the 'crowd' is not always 'wise' but could also make decisions driven by irrational discrimination (Ravina, 2016). Finally, the value of such soft information could decline as online lending goes mainstream and becomes automated.

\section{Regulatory challenge: How to ensure that lending-based crowdfunding platforms have sound due diligence and credit risk assessment without constraining credit scoring innovation?}

The problem of adverse selection is aggravated if lending-based crowdfunding platforms lend to riskier projects that are not financed by banks and, hence, no credit history exists to build robust scoring models. This appears to be the strategy of lending-based crowdfunding platforms that have difficulty attracting borrowers with banking relationships and, hence, try to scale-up by lending to riskier projects. A survey in the US finds that online lenders target SMEs that tend to be smaller, younger and less profitable than those borrowing from banks. It also documents that borrowers from online lenders have submitted more applications than borrowers from traditional banks (Wiersch et. al. 2016). A survey of Funding Circle, the largest UK platform that serves SMEs, shows that their borrowers choose crowdfunding because they do not have collateral (Pierrakis and Collins, 2013). De Roure et al. (2016) study borrowers from Auxmoney, the largest consumer P2P lending platform in Germany, finding that they pay a higher interest rate and are riskier than those of banks. Indeed, the website of Auxmoney explains that borrowers can receive a loan despite a bad credit rating provided by the Schufa, the German private credit bureau. Morse (2015) studies consumer lending in the US and also concludes that crowdfunding platforms' borrowers are likely to be more debt-laden and to be in more financial distress than the mean US borrower.

In this context, it is important to state that large traditional banks have a distinct informational advantage over lending-based crowdfunding platforms. Due to long-term banking relationships, banks possess granular data on their borrowers that allows them to model default risk. New entrants do not have access to this data and need to buy it. However, data provided by private companies is expensive and incomplete. These adverse selection problems constitute an important barrier to entry for new players, discussed in the next section. The disadvantage of new platforms could be diminished if they have access to information credit sharing schemes, such as public credit registries or private credit bureaus. The current regulations in Portugal, Finland and Belgium do not foresee this opportunity.

Regulatory challenge: How to diminish banks' informational advantage? Should platforms have access to the comprehensive data from public credit registries or private credit bureaus?

\section{Moral hazard and incentives}

Although the supervision of due-diligence and credit scoring models is a difficult task, the regulator should ensure that financial intermediaries should have proper incentives to do it. ${ }^{10}$ As more and more lenders are willing to rely on the automated lending function (where

\footnotetext{
${ }^{10}$ Moral hazard concerns have been pointed out as one of the main reasons for the banks' excessive risk taking before the global financial crisis. Banking business model has been compared to a put
} 
a lender can set lending criteria and automate lending), they delegate to the platform the task of screening and monitoring of borrowers. The existence of automated lending function decreases lenders' transaction costs, particularly when they want to diversify their portfolio by investing small amounts in numerous projects. Indeed, the existence of automated lending is essential for the scaling-up of lending-based crowdfunding because lowering transaction costs and diversification are two main reasons (along with liquidity provision and management of adverse selection problems) that explain the existence of financial intermediaries. In a number of countries, automated lending has been forbidden or not foreseen by the regulations (see more details in Table 1 and the Appendices A and B).

\section{Regulatory challenge: Allow or not automated lending?}

The business model of platform intermediation could be viewed as a form of 'originate and distribute model', which has undermined incentives to properly assess risks and has led to the build-up of risks before the global financial crisis (Keys et al., 2010). In the wake of the crisis, the regulators have imposed the risk retention requirement (a securitizer is required to retain at least $5 \%$ of the credit risk) to create economic incentives for securitizers to monitor the quality of the securitized assets. The ultimate goal is to help align the interests of securitizers with those of investors.

It appears that the risk retention requirement does not apply to the crowdfunding activity and in several countries, platforms are explicitly forbidden to invest in loans that they facilitate due to potential conflicts of interest (e.g. France, Germany, Israel and Portugal). The EU proposal also takes this position (See Table 1 and the Appendices A and B for more details). Despite such interdiction, some platforms design ways to invest in loans to signal their "skin in the game". In this case, to avoid any conflict of interest, platforms should be discouraged from cherry picking the best loans and should invest in all loans equally.

In several countries, lending-based crowdfunding platform have started to engage in the explicit securitization of loans that they facilitate (e.g. the US and the UK). In this case, the risk retention principle is obligatory in the US (Manbeck et al., 2017). In the UK, when Funding Circle securitized its loans, Moody, which rated the deal, noted that there was a potential misalignment of interest because Funding Circle did not have an economic stake in the securitization.

Regulatory challenge: How to align the interests of lenders and platforms? Should platforms be allowed to invest in loans that they facilitate (without cherry-picking) to align incentives between lenders and the platforms?

\section{Contingency or provision funds/Insurance}

Several platforms have set up contingency or provision funds that should smooth lenders' returns. There are different designs of provision funds in operation. While some platforms

option because bank owners participate only in the upside of their risk decisions, while their losses are limited to their paid-in capital. Such asymmetric pay-off encourages banks' excessive risk making. Hence, the objective of increased banks' capital requirements in the wake of the crisis is to render profits and losses more symmetric. This moral hazard problem is exacerbated by the explicit deposit insurance that reduces deposit interest rates and lowers market discipline (Demirguc-Kunt and Huizinga, 2004; Nier and Baumann, 2006). Furthermore, large banks that enjoy implicit government subsidies due to the 'too-big-to-fail' problems have incentives to take even more risks. 
propose to borrowers to pay a risk-adjusted fee into the provision fund, other platforms use their own capital to build a provision fund for retail lenders. In both cases, provision fund reimburses lenders if a borrower misses a payment. In the second case, first losses are absorbed by shareholders, which provides a mechanism to align the incentives of lenders and shareholders. Such mechanism is similar to the risk retention requirements (e.g. first loss tranche or first loss exposure) in the securitization, adopted in the wake of the crisis.

Most regulatory regimes do not mention and, hence, do not regulate provision funds (see more details in Table 1 and the Appendices A and B). Successful functioning of provision funds requires good scoring models that have a high predictive power of default rates. An alternative way of signalling the quality of their scoring models could be a requirement to publish expected default rate to allow lenders to compare it with the realized default rate (e.g. draft regulation in Israel).

Similar to provision funds set up by platforms, the Italian Ministry of Economic Development has created a State Guarantee Fund (Fondo di Garanzia) to help SME's access to credit. Although this guarantee can be only requested by financial institutions and institutional investors, Lendix has succeeded in offering it to individual lenders due to its business model that relies on a mix of private and institutional lenders. The guarantee is financed by borrowers' fees and covers at least $40 \%$ and potentially up to $80 \%$ of the outstanding capital of Italian projects in default.

The use of provision funds should not obscure the underlying risk to investors, who may believe that platforms are providing an implicit guarantee of the loans they facilitate (FCA, 2016). As platforms grow and diversify, the returns could become more stable and predictable. Nevertheless, platforms should issue risk warnings to explain to investors that, unlike banks, they do not offer risk transformation. In 2018, at least one platform has announced that it will guarantee $100 \%$ of capital (but not interest) due to the guarantee provided by an insurance company (e.g. Look\&Fin). This is an example of risk transformation and needs to be carefully supervised.

\section{Regulatory challenge: How to regulate provision funds and to ensure that investors know that, unlike banks, platforms do not perform risk transformation?}

\section{Capital requirements}

Minimum capital regulation could also help aligning incentives between lenders and platforms' shareholders. In most countries platforms should either respect a fixed minimum capital requirements (around 50000 euros) or to have a professional liability policy (see more details the Appendices A and B). The UK is the only country where minimum capital requirement is expressed as a percentage of loaned funds ${ }^{11}$. The existence of the minimum capital requirement in the UK is justified by the need to ensure the solvency of a platform in the presence of financial shocks. However, minimum capital requirements could also be used as a tool to provide incentives to platforms managers and shareholders not to expose the lenders to excessive risks. Part of the capital could be invested in a provision fund or directly in all loans (without any cherry picking) originated by the platform. While this would help to align the incentives of lenders and platform's owners, this is not allowed by regulations in many countries (including the EU proposal). Finally, it is also important to

${ }^{11} 0.2 \%$ of the first $£ 50$ million of that total value, $0.15 \%$ of the next $£ 200$ million of that total value, $0.1 \%$ of the next $£ 250$ million of that total value and $0.05 \%$ of any remaining total value. Platforms should have either $£ 50,000$ of capital or a percentage of loaned funds, whichever is higher. 
recognize that two objectives of capital requirement (platform solvency and a tool to align incentives) present an important trade-off that needs to be reflected in the level of minimum capital requirements.

Regulatory challenge: How to design minimum capital requirement that ensure (1) the solvency of a platform in the presence of financial shocks and (2) the alignment of incentives between lenders and platform owners?

\section{Resolution plans}

Prudent behaviour of lending-based crowdfunding platforms could be incentivized by the relatively simple resolution in the case of the platform failure. In other words, there should be no platforms that are too big or too interconnected to fail. While we have not yet experienced a failure of a large platform, theoretically, the business model of direct lending suggests that its resolution could be more orderly than that of a bank. Unlike the difficulty of implementing a bail-in that requires a precise classification of creditors' seniority, the business model of platform intermediation allows a built-in bail-in. Theoretically, if a platform fails, the return of lenders should not be affected by this failure because it depends only on borrowers' reimbursements. If orderly resolution is possible, this should solve the problem of 'too-big-to-fail' institutions, as well as decrease the need for explicit and implicit government guarantees and costly bail-outs.

As a matter of good practice, platforms could be required to have resolution plans in place. In other words, if a platform fails, loan repayments should continue to be administered and investors should not lose money solely as a result of the platform's failure. Most countries specify the need for the business continuity and in France platforms are even required to sign a contract with a third-party payment institution to ensure business continuity (see more details the Appendices A and B). However the details of such plans are unknown. Also for this reason, the regulation often specifies that clients' money should be held in a special trust account (e.g., Israel and Mexico), or in most countries platforms do not even have the right to handle clients' money and should rely on a payment institution or obtain a license of a payment institution to do this. In France, a limited payment license was put in place for crowdfunding platforms, but platforms prefer to rely on a third party.

In practice, a survey undertaken by the CCAF in the UK finds that lenders are not very confident that they would recover their funds in the event of platform failure. For both P2P consumer and property lending, only $11 \%$ of funders are confident that they would recover their investment which is slightly above the $9 \%$ of funders for P2P business lending and debt-based securities. According to the FCA (2016), the resolution plans of some platforms are inadequate to successfully run-off loan books to maturity. Special attention should be paid to the resolution plans of platforms that pool risk and propose lenders to invest in a portfolio. The reliability of the third party is also essential. Some platforms rely on other start-ups to fulfil this role, which is a delicate strategy because start-ups are more likely to fail. In some countries, regulation does not specify the need to have business continuity requirements (e.g. Austria, Finland, Germany, Mexico) or does not specify the need for a third party. While the EU proposal requires platform managers to ensure business continuity, no specifics are provided.

Regulatory challenge: How to design resolution plans so that, if a platform fails, loan repayments will continue to be administered (by a third party) and investors would not lose money solely as a result of the platform's failure? 


\section{Institutional investors}

Most platforms allow investment of sophisticated institutional lenders, such as insurance companies, banks, hedge funds, investment groups or family offices that could have their own scoring models. In 2016, the first British consumer lending platform, Zopa, has signed an agreement with a challenger bank, Metro, that will allow the latter to lend via the site of the crowdfunding platform. A number of platforms operate through a co-financing model: the projects selected by the platform are financed both by institutional and retail investors. An important feature of such partnerships is the institutional investors' guarantee to automatically finance the project if retail funding is insufficient. This provides an important guarantee to borrowers that their loans will be funded. In business models that only rely on retail funding, borrowers face funding risks because their loans might not be funded.

Figure 9. The share of institutional investors in lending-based crowdfunding platforms

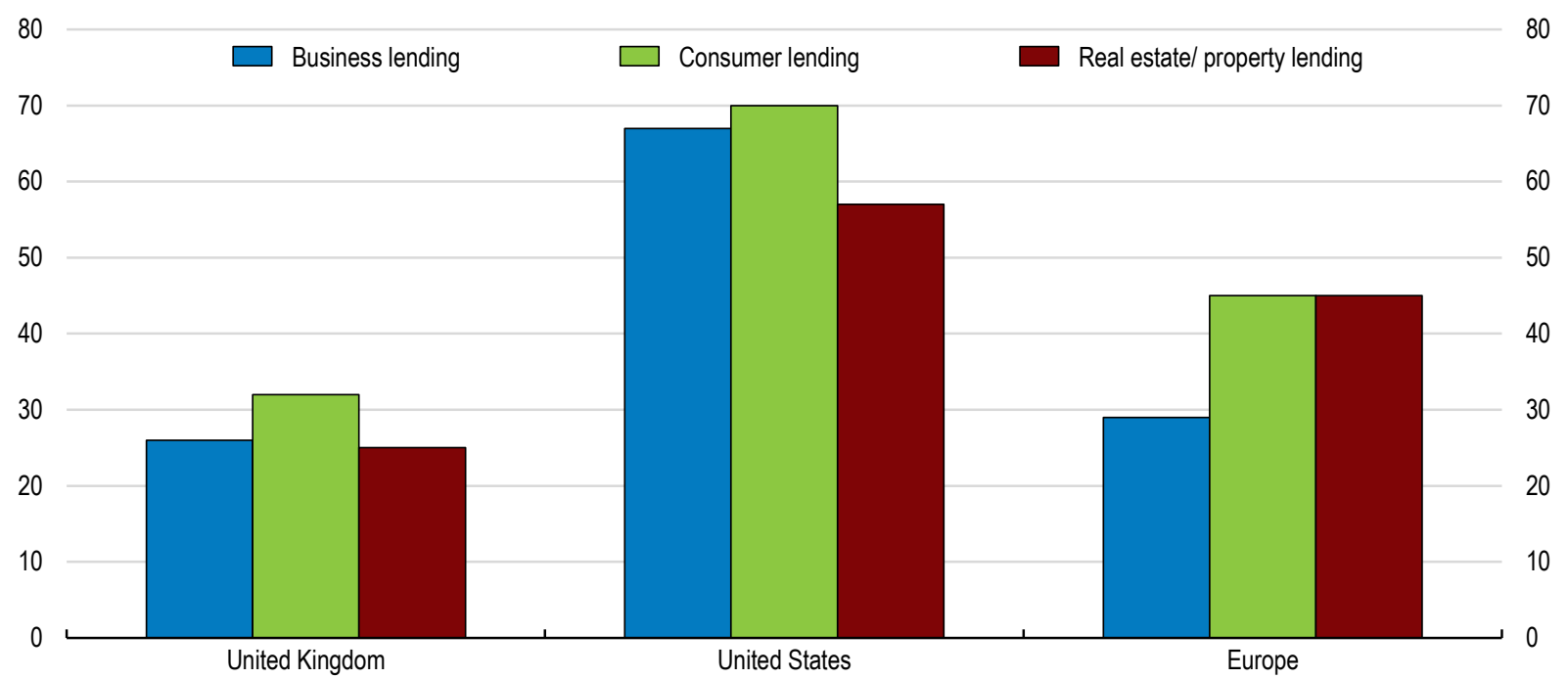

Source: Cambridge Center for the Alternative Finance.

Despite such obvious benefits for borrowers, institutional investment in lending-based crowdfunding platforms could also pose risks. Figure 9 shows that the share of institutional investors is particularly high in the US and the explanation is likely due to the regulation that restricts or curtails accredited and non-accredited investor involvement in the US (Ziegler et al., 2017). The high reliance on institutional investors explains why in the US the term 'P2P lending' was replaced with 'marketplace lending'. Most of this institutional investment takes form of asset-backed securities (ABS) with the participation of rating agencies (DBRS, Fitch, Kroll, Moody's and S\&P) and large investment banks (e.g. Goldman Sachs, Morgan Stanley, $\mathrm{Citi}^{12}$ ). There is less data on buyers of ABS, but there are risks that many of them are leveraged and 'too-big-to fail' institutional investors that are prone to runs, moral hazard problems. Then, hedge funds and investment banks can use ABS as collateral for borrowing money on the money market. In this case, lending-based crowdfunding platforms become just an element in the chain of the shadow banking.

12 PeerIQ tracks this securitisation activity with monthly reports about volumes, spreads, credit performance as well as participation of rating agencies and investment banks. 
Importantly, all the advantages of the crowdfunding business model that are identified in this paper (e.g. less prone to runs, no leverage, easy resolution) would be lost.

The business model of some lending-based crowdfunding platforms, in particular how much screening they do before listing borrowers on their webpage, might give an advantage to institutional investors. While some platforms only lightly pre-screen borrowers (and provide a lot of information to allow investors to screen borrowers themselves), others rigorously screen borrowers (and provide less information to investors). Not surprisingly, the first kind of platforms gives an advantage to sophisticated investors. Vallee and Zeng (2018) provide empirical evidence of sophisticated investors' outperformance but show that it has become lower in recent years. In the UK, many market observers feel that institutional investors as well as high net worth individuals and parties related to a crowdfunding platform have sought or received inappropriate preferential treatment, such as early or exclusive access to loans, greater access to information about borrowers or the option to opt-out from lending to segments of the market (FCA, 2016). In light of this discussion, it is important to ensure that institutional investors do not have the chance to cherry pick the best loans at the expense of the crowd who would be left with risky projects. Platforms should have mechanisms to ensure fair treatment of retail and institutional investors and supervisors should ensure that the latter do not receive preferential treatment. While most regulators require platforms to have mechanisms to avoid such conflict of interest, how this is done in practice is not always clear.

\section{Regulatory challenge: How to ensure that lending-based crowdfunding platforms are not too interconnected with leveraged institutions? How to ensure fair treatment of retail and institutional investors?}

\section{Transparency and disclosure}

Finally, a simple model of lending-based crowdfunding, where investors can observe the composition of their loan portfolio and risk level, could commit platforms to choose lower default risk. This is in line with the earlier literature about the role of market discipline, transparency and disclosure on risk-taking behavior of banks and asset managers. Sato (2014) shows that if asset portfolios are opaque, managers with greater career concerns are more inclined to lever up secretly in an effort to inflate investor expectations about their funds' future performance. Cordella and Yeyati (1998) show that if risk is endogenous, bank failures are less frequent in a transparent setting due to market discipline. Their theoretical model is confirmed by Nier and Baumann (2006) who study a sample of 729 banks in 32 countries and find that banks with higher disclosure standards take less risks and hold more capital.

By definition, platforms adhere to higher disclosure standards than banks and regulation requires platforms to publish an extensive amount of information (see for more details the Appendices A and B). They provide elements of balance sheet and income statement for each borrower, information about the purpose of the borrowed funds, as well as a risk score attributed by the platforms. Sometimes, but not always, such information is provided in a convenient format of a loan-book, i.e. an excel file with the list of all borrowers and essential information about them. For example, members of the UK P2P lending association are expected to do this. While these data might not be used by all retail investors, such information can be analysed by third parties (institutional investors, business analyst, researchers, investor protection organizations) to asses risks.

Although individual crowdfunding platforms are relatively transparent and present a large number of information on their web-pages, consistent reporting standards for loan 
origination data and portfolio performance are lacking. It is virtually impossible to find aggregated information to compare information about borrowers on different platforms as well as platform performance. One option would be for the supervision authorities to compile and publish such data. The US Treasury Department has recommended the creation of a private sector registry for tracking data on transactions, including the issuance of notes and securitizations, and loan-level performance. The French supervisor provides an explicit formula for calculating platforms' default rate to ensure the consistency of the reported information.

The transparency of the crowdfunding was born as a reaction to the opacity and complexity that has contributed to the global financial crisis. It is important to preserve this business model from potential attempts to obfuscate investors. Past experience shows that in order to preserve their information rents, financial institutions could alter their retail product offerings and in this way "interfere" with the learning of unsophisticated investors (Carlin and Manso, 2011). Notably, one of the largest platforms was excluded from the UK P2P lending association because of the lack of transparency. Platforms that pool risk and propose lenders to invest in loan portfolios should still publish detailed information on all borrowers. The FCA (2016) has voiced concerns about how some firms are presenting information to investors (e.g. misleading comparisons with savings accounts and banking).

Regulatory challenge: How to ensure high disclosure standards of crowdfunding platforms to enable market discipline? How to ensure that lending-based crowdfunding platforms do not present their products as instruments similar to banking savings accounts?

\section{Market power and barriers to entry}

The final rationale for the regulation is market power and weak competition. It is too early to think about the market power of crowdfunding platforms ${ }^{13}$. On the contrary, lendingbased crowdfunding is viewed as an instrument to increase competition in lending markets for consumers and businesses. Crowdfunding platforms are entering the market dominated by large incumbent banks that, on the one hand, suffer from inefficiencies, high leverage, opacity and rent-seeking (Philippon, 2016), but on the other hand are considered as toobig-to-fail and enjoy lower funding costs (Schich and Lindh, 2012).

As any entrant, lending-based crowdfunding platforms could face important barriers to entry: i) regulatory barriers, ii) structural barriers because of economies of scale and scope, switching costs, lack of data, iii) strategic barriers if incumbent banks try to deter entry. This section describes these barriers and explains strategies used by platforms to overcome them and to compete with banks. By doing so, we explore the role of the regulation and public policy to ensure an even playing field.

\footnotetext{
${ }^{13}$ Although the market share of crowdfunding platforms in the lending markets is very small, the market share of the largest platforms in the lending-based crowdfunding market is rather high. For example, in the UK, Funding Circle controlled 67\% of business lending in 2017 (compared to 60\% in 2016), while in France, Lendix controlled 60\% of business lending in 2017 (compared to 54\% in 2016). The existence of the European passport could allow platforms to compete at the European level.
} 


\section{Regulatory barriers}

The crowdfunding platform's decision to enter or not depends on the designed regulatory framework and a regulator may influence platforms' entry costs and impact the structure of the credit market through regulatory requirements (e.g. minimum capital requirements, regulation of platforms' business model, banks' monopoly to extend a loan, fiscal advantages, access to the credit information sharing scheme, etc). A flexible and friendly regulatory and supervisory approach allows platforms to experiment with different business models. It is helpful if the financial supervisor has an operational objective to promote effective competition in the interests of consumers. For example, the FCA has comprehensively investigated the competition in credit market for consumer and small business lending and it recognizes that lending-based crowdfunding has the potential to exert beneficial competitive pressure (FCA, 2016).

First lending-based crowdfunding platforms have entered without any regulation and the authorities in several countries have intervened. Prosper Marketplace offers an interesting case study of the regulatory barriers. In 2006, Prosper launched the first online P2P consumer lending platform in the US. At the end of 2008, the Securities and Exchange Commission (SEC) issued a "cease and desist" order against it because it considered that the sale of unregistered securities represented a violation of Section 5 of the Securities Act of 1933. Zingales and Winter Dominguez (2017) provide another example of how regulations create barriers to entry with an example of Cumplo, a Chilean P2P consumer lending platform. Alerted by a traditional bank, the Bank of Chile has threatened to close the platform and to jail the platform founders for serving as "money broker" and violating the General Banking Law. In a press release to face these accusations, the founders claimed that authorities have never been so harsh in prosecuting usury and financial abuses as they have been in trying to shut down a small start-up. In Poland, the amendment to the law on consumer credit, published in 2016, requires that lending activity is conducted only by the legal persons, which has virtually outlawed lending-based crowdfunding platforms that started to operate on the Polish market.

The above examples suggest that the lack of the appropriate regulation could be a major barrier for the development of lending-based crowdfunding. This is why, a growing number of countries have decided to establish a specifically-designed regulatory framework, described earlier. Other countries are consulting with the stakeholders about the benefits of the regulation tailored to the new entrants (e.g. Ireland, the Netherlands, Poland, Sweden) (KNF, 2017; Irish Department of Finance, 2018). In response to the Irish consultation, all of the participants were in favour of regulation, noting that it should be proportionate and that it should not impact the development and growth of the industry (Irish Department of Finance, 2018). As a caveat, there are a number of successful platforms that are based in countries without the legal framework specifically designed for lending-based crowdfunding (e.g. the US, Germany, the Netherlands, Estonia).

The lack of the appropriate regulatory framework could introduce uncertainty, additional regulatory burden (due to the need to have additional licenses that are needed for payment services and secondary markets) and higher costs due to the need to rely on the third parties. For example, in countries without specifically designed lending-based crowdfunding legislation, banks still have the monopoly to extend credit (e.g. the US, Germany) and crowdfunding platforms need to cooperate with banks that originate loans. The platform passes through the origination fee to the borrower and the lenders. Interestingly, such 'fronting' services are always provided by small banks that have themselves difficulties to scale in the market dominated by big institutions. It is important to mention that in some 
countries that have introduced a specific crowdfunding regulation, platforms are still forbidden from originating loans (e.g. Austria and Belgium).

The regulatory heterogeneity and uncertainty have been identified as a major barrier of entry for the cross-border activity in the EU (EC, 2017). This has motivated the European authorities to propose the EU-wide license for the lending-based crowdfunding platforms. As a caveat, a temporary absence of the euro-wide regulatory regime for crowdfunding could have been beneficial for the market entry and competition. Specifically, several platform founders in France have stated that the absence of the euro-wide crowdfunding passport has protected them from competition with large foreign platforms that decided not to enter the European market due to the fragmentary regulation of crowdfunding. This has allowed the entry of local crowdfunding players at the initial stage. However, the scaling of these actors requires a Europe-wide regulation.

Many policymakers recognize that having a legal framework is not enough and, hence, they encourage experimentation of business models, processes and products. The UK has established a regulatory sandbox (that allows testing innovative products in a controlled environment with tailored policy options) and other countries have followed or are considering this approach (e.g. Australia, Canada, Israel, Mexico, the Netherlands, South Korea, Switzerland). Several countries have established accelerators that allow start-ups to develop their ideas that result in a pitch presentation (e.g. BoE Fintech Accelerator, Le Lab Banque de France). A majority of countries have established innovation hubs and central points of contact to provide clarifications regarding the legal framework applicable for Fintech start-ups ${ }^{14}$. The EU Fintech Action Plan calls the European Commission to present a report with best practices for regulatory sandboxes by Q1 2019.

Last but not least, even when there are no explicit regulatory barriers, favourable government policy towards incumbent banks represents a significant barrier to entry. For example, explicit and implicit government guarantees imply a funding cost advantage to large banks that is extensively documented in the literature (Schich and Lindh, 2012). From this follows that, all other things being equal, large banks can provide credit at a lower interest rate than crowdfunding platforms. This hypothesis appears to be confirmed by the Small Business Credit Survey in the US (Federal Reserve, 2017) that documents high interest rates are one of the main reasons behind borrowers' dissatisfaction with online lenders.

\section{Regulatory challenge: How to ensure that policies towards incumbent banks (such as explicit and implicit guarantees) do not distort the level playing field between banks and platforms?}

\section{Natural or structural barriers}

New entrants face structural barriers to entry because of economies of scale and scope, network effects, ownership or control of a key scarce resource and switching costs. Lack of data and adverse selection problems, described in the previous section, represent one of the most important barriers to entry for lending-based crowdfunding platforms. It is also

14 For example, in Austria - Fintech Point of Contact within the Austrian Financial Market Authority; in France -ACPR FinTech Innovation; in Portugal - a Financial Innovation department within the CMVM; in Belgium - a Fintech Portal ("innovation hub") that is managed jointly by the FSMA and the National Bank of Belgium; in Poland- KNF Innovation Hub and Special Task Force for Financial Innovation; in Sweden - Innovation Center at the Financial Supervisory Authority (Finansinspektionen), in Norway - a FinTech working group established by the FSA. 
obvious that technology-enabled arm's lengths (or transaction-based) processing offers distinct scale economies (Boot, 2017) and, for crowdfunding platforms, achieving the necessary scale to compete with banks could be difficult. There is also an extensive literature documenting important scope economies between joint deposit-taking and lending (Mester et al., 2007).

Financial sector is also characterized by high switching costs that increase entry costs (Shy, 2002; Kim et al., 2003). In the investigation conducted by the Competition and Markets Authority (CMA) in the United-Kingdom (2015), switching rates for bank current accounts are estimated at 4\% in 2014 for SMEs. The Charterhouse follow-up survey (2014) reveals that $90 \%$ of SMEs went to their main bank to obtain overdraft, loans and credit cards, whereas $69 \%$ considered their main bank for invoice discounting and factoring, and $76 \%$ for commercial mortgages.

Low switching rates and high loyalty is the outcome of numerous factors. On the one hand, banks may be engaged in long-term relationships with their consumers (i.e., relationship banking) and could be in a better position to assess lending risks due to better scope economies (e.g. current account data) and local knowledge. Some SMEs believe that loyalty to their bank can help them in the future if they face an episode of financial distress and, importantly, such beliefs are validated by the economic theory and the empirical evidence. On the other hand, switching costs include financial costs, search costs, learning costs, cognitive effort, emotional costs, as well as financial, psychological, and social risks. Search costs in the credit market are high and prices are often difficult to compare. A very small percentage of SMEs and consumers use price comparison websites. Empirical evidence suggest that young, urban and more educated individuals have lower learning costs and are more likely to apply for credit via a crowdfunding platform (Havrylchyk et al., 2018), which is in line with earlier evidence about the adoption of other innovations, e.g. electronic banking (Kennickell and Kwast, 1997).

In this context, it is particularly important to ensure that consumers receive correct and timely information about lending-based crowdfunding platforms. The following incident shows the importance of the independent research on the topic. In February 2017, the French consumer protection association, UFC-Que Choisir (2017) published a report about performance of French lending-based crowdfunding platforms. It argued that despite high advertised returns of these platforms, the realized net returns (after defaults and taxation) were lower than the return on risk-free bank deposits, such as Livret A. French association of the alternative finance (Finance Participative France) and leading lending-based crowdfunding platforms have contested the methodology and findings of the UFC-Que Choisir. The supervisors, the AMF and the ACPR, have not issued an opinion. Researchers could not react because the necessary data was not easily accessible.

In the above example, it is likely that the supervisors have not issued an opinion because they devote very few resources to the supervision of lending-based crowdfunding platforms. For example, in France where there are dozens of crowdfunding platforms, the equivalent of one man per year is devoted to controls; in Portugal - 2 employees; in Israel -3 persons are responsible for the supervision. While these limited resources are justified by the fact that crowdfunding does not pose systemic risk, the novelty of this phenomenon could require more resources. Importantly, most researchers study crowdfunding platforms only in countries where data are readily available (e.g. the US), while few researchers investigate EU platforms due to the lack of readily available loan-book data in a convenient format (Havrylchyk and Verdier, 2018). Regulators and supervisors could encourage the analysis and research in this field, in particular regulatory policy evaluations. In particular, 
regulators could contribute to the creation of new knowledge, such as development of databases and surveys.

\section{Regulatory challenge: How to lower search costs and learning costs to allow consumers to have sufficient information about new actors and to facilitate switching to new technologies?}

\section{Strategic barriers}

Banks may also erect strategic barriers to deter online lenders from entering the market. For example, in markets, in which crowdfunding platforms are forced to rely on a bank to originate loans, banks could raise origination fees (i.e., to raise their rivals' costs). Another possibility is that banks react by investing in technological improvements. Several banks have started to launch their own online lending platforms (e.g., Commerzbank in Germany launched "Main Funders", Rabobank in the Netherlands launched "Rabo \& Co"). Both banks argue that the motivation for launching platform is to remove the balance sheet impact of credit to SMEs. In other words, to remove the need for capital requirements, Banque Postale in France has acquired a lending-based crowdfunding platform Lendopolis (along with the reward-based crowdfunding platform KissKissBankBank) and has acquired a share in a platform WeShareBonds that facilitates minibonds. Bank ING Diba acquired Lendico. Finally, new entrants that offer payment services have also decided to offer loans to SMEs (e.g., PayPal, Amazon...) due to the complementarity between information from transaction processing and credit.

One could assume that, thanks to internet, the ability of banks to erect some strategic barriers could be declining. For example, incumbent banks used to have an incentive for branch proliferation to such an extent that an entry with an additional network would become unprofitable (Vives 1991). Branches are also a form of advertising for banks and branch density could play an important role in the bank's advertising strategy to develop brand loyalty (Dick, 2007). These theories are supported by numerous empirical studies that demonstrate a negative correlation between branch density and market entry (Adams and Amel, 2016). Havrylchyk et al. (2018) show that US borrowers from counties with higher branch density are less likely to apply for a credit via a crowdfunding platform. This implies that bank proliferation strategy might still work in the age of internet.

\section{How to overcome barriers?}

To overcome barriers to entry, crowdfunding platforms need to choose whether to target SMEs that are not served by incumbent banks (the market expansion strategy) or offer differentiated services to banks' customers (the differentiation strategy). The strategy of market expansion is dangerous. If entrants serve only consumers that are rejected by banks, they risk to have higher default rates and lose servicing fees. Indeed, as shown in Dell'Ariccia et al. (1999), adverse selection in lending markets is a significant barrier to entry.

In the differentiation strategy, online lenders may offer different debt products (invoice financing, loans without collateral, etc.). There is some anecdotal evidence that in France, SMEs do not have difficulty to obtain a bank credit with collateral but they turn to crowdfunding platforms to finance projects without underlying tangible assets (new marketing strategy, research and development, hiring a new salesperson). However, this strategy still means that platforms lend to projects that were not financed in the past and, hence, scoring models cannot rely on the credit history. 
Although the volume of debt-based crowdfunding continues to grow, it is still not clear how platforms can scale up beyond the niche market of solvent borrowers underserved by banks. There is a risk that lending-based crowdfunding platforms tap ever riskier market segments. For example, Vallee and Zeng (2018) show that the two largest US consumer marketplace lending platforms (Lending Club and Prosper) loosen their screening standard in terms of FICO score and debt-to-income ratios. As a result, delinquencies and cumulative losses on newer vintages are higher than those seen on older vintages at the corresponding loan age (PeerIQ, 2017), despite the decline of banks' delinquency rate on consumer loans during the same time. Such initial market expansion towards risky segments of the market could be a viable strategy only if platforms succeed in later stages to attract less risky borrowers and to compete with banks for prime borrowers.

At the moment, most crowdfunding platforms are still making losses, because they have not achieved a sufficient scale to cover their fixed costs (Milne and Parboteeah, 2016). Reaching profitability is a difficult task because of network effects and the need to attract a critical mass of users. Indeed, incumbent banks already have an installed base of clients, which gives them an advantage over lending marketplaces, that is, the presence of large volume of deposits and the existence of long term lending relationships with SMEs. The economies of scope between lending and deposit activities erects a structural barrier for the entrants that do not offer deposits. The management of current accounts is particularly helpful to offer overdraft credit, which is one of the most common forms of lending to SMEs in some markets (e.g., United-Kingdom, see the CMA Report, 2015). The PSD2 Directive, which requires banks to grant third-party providers access to customer payment accounts, could lower banks' advantage in this area.

While market expansion is difficult in normal times, this strategy appears to have worked in the wake of the global financial crisis. Since banks needed to deleverage, a wider and more creditworthy pool of potential borrowers appeared (Atz and Bholat, 2016). Using the US data at the county level, Havrylchyk et al. (2018) find that borrowers from counties where banks are overleveraged applied for crowdfunding credit more often that those located in counties with solvent banks. Koetter and Blaseg (2015) also show that bank instability in Germany has pushed businesses to use equity crowdfunding as a source of external finance. Furthermore, survey evidence suggests that the impact of the global financial crisis could be long-term due to borrowers' mistrust of the traditional banking sector. In response to the question about the main advantages of borrowing from a P2P lending platform, 54\% of Funding Circle's borrowers responded that it is 'Not my bank'. The only response that was more popular was 'speed of securing finance' (58\%) (Pierrakis and Collins, 2013). This suggests that the choice to use P2P lending platforms could be permanent even when banks deleverage and pick-up their credit supply.

\section{Cooperation between platforms and banks}

To overcome the barriers to entry, crowdfunding platforms have chosen to cooperate with banks and other institutional investors. There are three major cooperation mechanisms: i) loan origination by banks, ii) banks' investment in loans originated by platforms or investment in platforms, iii) distribution partnerships with banks. The first two mechanisms were discussed earlier. As to the distribution partnerships, in the UK, Santander was the first bank to refer customers to the Funding Circle. Lendix, the largest French platform, has announced in 2018, a distribution partnership with Matmut, an insurance company. From the perspective of platforms, banks' investment in loans issued via platforms releases liability side constraints (finding lenders), while distribution partnerships release asset side constraints (finding borrowers). As of beginning 2018, one can conclude that the above 
investment partnerships with banks and other institutional investors have relieved platforms' constrains on the liability side. Some platforms have even stopped accepting retail investors' funds because the supply of funds largely surpasses the demand for funds ${ }^{15}$.

While both banks and platforms can benefit from the cooperation, such strategy is by essence fragile. It is particularly difficult to imagine a direct competition between banks and crowdfunding platforms in countries where banks have a monopoly to originate loans. If banks perceive platforms as a competitive threat, they may erect strategic barriers to entry by raising their rivals' costs (e.g. the fees charged to originate loans), by withdrawing funding and stopping distribution partnerships. A possible solution to this problem was proposed in 2016 by the UK government when it has made the referral schemes mandatory for nine of the largest British banks. If a small business (with turnover of below $£ 25 \mathrm{mln}$ ) is rejected by a big bank, the bank is now obliged to refer the business to one of the three designated credit brokers regulated by the FCA. In turn these credit brokers should help match the SME with other alternative finance provides, such as crowdfunding platform, which could offer viable businesses the finance they need.

\section{Regulatory challenge: Should referral schemes that oblige large banks to refer rejected small businesses to alternative credit providers become mandatory?}

\section{Competition with banks}

To scale up, crowdfunding platforms need to enter in direct competition with banks and surveys provide a first set of evidence that this is happening. In the US, $60 \%$ of online applicants also applied to a traditional lender (Wiersch et. al. 2016). However, the remaining $40 \%$ applied only online, revealing that the large share of small businesses that seek credit online could be considered as a market niche. A report by Deloitte (2016) cited by the FCA (2016) shows that the main drivers of competition between banks and platforms are the ease of application and the speed in decision-making rather than interest rates (though interest rates also figure as a driver). This view is confirmed in the CMA Report in the United-Kingdom (2015), since interest rates are the most important factor driving the choice of a credit offer for only $26 \%$ of SMEs. According to the CMA Report (2015), one quarter of SMEs thought that alternative platforms were faster and more flexible than traditional banks. A survey conducted by CEBR (2016) on Funding Circle business borrowers in the UK found that the main reason for small businesses to borrow through Funding Circle were the speed of the process $(31 \%)$ and the simplicity of the loan application process $(28 \%)$.

In 2016, Zopa, the first P2P lending platform, announced that it was applying for a UK banking license. This is symbolic because Zopa has created the business model of P2P lending and its application for the banking licence signifies, on the one hand, the limits of the platform business model and, on the other hand, its similarity with the banking model. The platform mentions that this will enlarge the scope of lending products that are offered to its customers (e.g., overdraft credit) and offer protected depository accounts. Indeed, as mentioned earlier, the management of current accounts is essential for lending to SMEs,

\footnotetext{
${ }^{15}$ Milne and Parboteeah (2016) argue that both in the United-States and in the United-Kingdom, it the beginning it was much more difficult to persuade depositors than borrowers to join lending marketplaces, because depositors benefit from the deposit insurance protection in case of a bank failure. Furthermore, platforms do not offer the same liquidity services as banks. This explains why platforms have focused on opening the market to institutional investors, on creating secondary markets to resell loans and offering provision funds to investors.
} 
because the latter often do not search for other finance providers than their main bank. This raises the issue of whether the business model of a pure player as a platform that operates online only is viable.

\section{Government policies to support lending-based crowdfunding}

The above discussion illustrates that lending-based crowdfunding platforms face high barriers to entry that are often structural in nature. Hence, in many countries authorities design policies that support lending-based crowdfunding.

In particular, development banks lend via crowdfunding platforms and invest in them, which could provide a valuable signal that the crowdfunding business model is viable. The British Business Bank was the first state bank to finance SMEs via loans issued by crowdfunding platforms. First investment was made in December 2012 in which $£ 20$ million of state funds were lent out via Funding Circle by the Business Finance Partnership (a predecessor to the British Business Bank). Starting from the establishment of the British Business Bank in 2014, it has lent $£ 135$ million via crowdfunding platform with different business models, such as Funding Circle, MarketInvoice, RateSetter and Zopa. These investments had a multiplier effect because as each loan was repaid, the funds were available for another business to draw upon. In 2016, the European Investment Bank and the KFW, the German state-backed bank, have invested almost $£ 130 \mathrm{~m}$ in Funding Circle’s securitized loans. In 2017, the Bpifrance, the French state investment bank, has decided to co-finance loans originated by Lendix, the largest French platform. It was shortly followed by the European Investment Bank (via its European Investment Fund) that has decided to co-finance $18.5 \mathrm{mln}$ Euros of loans originated by Lendix. The Enterprise Ireland, the Irish Governmental agency responsible for investment and the development of Irish businesses internationally, has invested in GRID Finance, the Irish lending-based crowdfunding platform.

Also, authorities in several countries have adapted their taxation policies to lending-based crowdfunding. Notably, lenders are able to subtract crowdfunding losses from their revenues in the calculation of the tax base. In some countries, revenues from some financial products are tax-free and the authorities have introduced similar benefits for the crowdfunding activity. For example, the UK Government introduced the Innovative Finance ISA (IFISA) in April 2016 which allows lending-based crowdfunding activities to be eligible for a new tax-free ISA. The French government has announced in 2018 that bonds and minibonds raised via crowdfunding platforms will be eligible for the favourable tax treatment that is already applicable to other sources of SME financing (this facility is called in French PEA-PME).

\section{Regulatory challenge: How to adopt taxation policies to lending-based crowdfunding? Should lenders be able to subtract their crowdfunding losses from their revenues in the calculation of the tax base?}

The state support reflects the optimistic position of many authorities that crowdfunding, and FinTech general, could promote more competitive financial markets. For example, in its press release on 8 March, 2018, the EC stated that crowdfunding improves access to funding especially for start-ups and other small businesses (EC, 2018b). Such statements are not yet supported by hard evidence. The available empirical evidence points to the fact that crowdfunding serves riskier segments of borrowers, but it is still too early to conclude about its overall impact on economic growth and productivity (Havrylchyk and Verdier, 2018). While government support could be an essential tool in promoting the development 
of lending-based crowdfunding platforms and helping crowdfunding platforms to overcome high barriers to entry, it would be worth considering accompanying it with impact assessments.

\section{Regulatory challenge: How to assess the impact of state supporting and regulatory policies?}

\section{Conclusions}

This paper tried to establish a framework that allows to think about the regulation of lending-based crowdfunding platforms and to identify regulatory challenges. Although lending-based crowdfunding platforms do not technically perform risk and maturity transformation, they could be viewed as an alternative to the banking business model if they implement automated lending (to lower transaction costs and permit diversification), provision funds (to play the role of delegated monitor) and secondary markets (to provide liquidity). It argues that there are good reasons to believe that platform-based intermediation could be more stable than banking intermediation for two main reasons. First, even in the presence of secondary markets, platforms are not subject to self-fulfilling runs. Second, the resolution of a crowdfunding platform in the case of the failure could be more orderly due to the direct links between lenders and borrowers, diminishing moral hazard concerns.

A number of countries have designed specific regulatory regimes for lending-based crowdfunding platforms (or for investment-based crowdfunding platforms that allow debt securities). In March 2018, the EU has published its proposal for the regulation of crowdfunding services. These new regulations vary with respect to what activities are allowed or forbidden. The UK regulation is the most flexible because it explicitly sets high limit on maximum size of loans $(£ 5 \mathrm{mln})$ and allows origination of loans, automated lending, provision funds, secondary markets and platforms' investments in loans that they facilitate. In contrast, the EU proposal does not mention capital requirements and automated lending, sets low maximum size of loans (EUR $1 \mathrm{mln}$ ), explicitly forbids platforms' investment in loans and limits the responsibility of platforms in the organization of the secondary markets (called bulletin boards).

Restricting crowdfunding platforms to simple credit intermediaries limits their risks, but it also prevents them from experimenting with different business models that could allow them to perform the same functions as banks but with a less fragile business model. For example, many authorities forbid platforms' investment in loans that they facilitate fearing a conflict of interests due to cherry-picking. The EU has also chosen this approach in its proposal. If platforms do not retain risk, their business model resembles an "originate and distribute" model of the securitization process that was pointed out as one of the major causes of the global financial crisis due to wrong incentives. Moral hazard problems are inherent in the financial intermediation and the success of lending-based crowdfunding platforms will likely hinge on their ability to align incentives between platforms and lenders. This issue should be the keystone of any financial regulation.

Not all innovation in platforms' business models is beneficial in terms of financial stability. Several platforms appear to promise transformation of risk and maturity, which automatically transforms them into shadow banks. In some countries, particularly in the US, platforms securitise their loans and sell ABS to leveraged and 'too-big-to-fail' institutional investors that are prone to runs and moral hazard problems. In these cases, lending-based crowdfunding platforms risk to become an element in the chain of the 
shadow banking. Importantly, all the advantages of the crowdfunding business model that are identified in this paper would be lost.

The objective of the regulation should be to level the playing field for new market entrants that are facing numerous barriers to entry (regulatory, structural and strategic). Having a specific lending-based crowdfunding regulatory regime might not be enough for their scaling up. Lending-based crowdfunding platforms face a combination of adverse selection problems and high switching costs, which has forced them to pursue the market expansion strategy towards risky borrowers. While this strategy could work at the initial stage, the long-term viability of the crowdfunding business model is likely to require a direct competition with banks for good borrowers. This might require flexible regulation that allows lending-based crowdfunding platforms to experiment with different business models in order to fulfil the same functions as banks. An access to the information sharing scheme is essential for solving adverse selection problems. Some authorities are considering policies to facilitate switching to new technologies and even directly invest via lending-based crowdfunding platforms.

Many policymakers appear to be optimistic that crowdfunding, and more generally Fintech, could promote more competitive financial markets. For example, in its proposal for the crowdfunding regulation, the EC states that crowdfunding improves access to funding for start-ups and other small businesses (EC, 2018b). Such statements are not yet supported by robust evidence and require further research. While flexible regulation could allow platforms to experiment with different business models, it should be done under the watchful eye of the supervisors and independent researchers. Currently, supervisory authorities devote few resources to the supervision of lending-based crowdfunding platforms. While these limited resources are justified by the fact that crowdfunding does not pose a systemic risk, the novelty of this phenomenon and its potential, may require more human resources. When it comes to researchers, most of them study crowdfunding platforms only in the US where data are readily available and few researchers investigate EU platforms due to the lack of readily available loan-book data in a convenient format. To generate new knowledge in this field, policymakers need to encourage policy evaluations as well as development of databases and surveys. 


\section{Bibliography}

Belleflamme, P., Omrani, N., Peitz, M., 2016. The Economics of Crowdfunding Platforms. CESIfo DICE Report, Volume 14.

Beck, Thorsten and Carletti, Elena and Goldstein, Itay, Financial Regulation in Europe: Foundations and Challenges (March 2016). CEPR Discussion Paper No. DP11147.

Berg, T., Manju Puri, and Jörg Rocholl, 2015, "Loan Officer Incentives and the Limits of Hard Information," Working Paper, Duke University.

Boot, A. W.A., 2017. The Future of Banking: From Scale \& Scope Economies to Fintech, European economy. Banks, regulation, and the real sector

Buchak, G., G. Matvos, T. Piskorski, A. Seru, 2017. Fintech, regulatory arbitrage, and the rise of shadow banks, NBER Working Paper No. 23288

Davis, K. and J. Murphy, 2016. Peer-to peer lending: Structures, risks and regulation, JASSA The Finsia Journal of Applied Finance 3.

Demirguc-Kunt, Asli \& Huizinga, Harry, 2004. "Market discipline and deposit insurance," Journal of Monetary Economics, Elsevier, vol. 51(2), pages 375-399, March.

De Roure, C., L. Pelizzon, P. Tasca, 2016. How does P2P lending fit into the consumer credit market? Deutsche Bundesbank Discussion Paper No 30/2016

Diamond, D.W., 1984. Financial intermediation and delegated monitoring. The Review of Economics Studies, 51 (3): 339-414.

Diamond, D. W. and P. H. Dybvig, 1983. Bank runs, deposit insurance, and liquidity, Journal of Political Economy 91(3):401-419.

EBA (2015). Opinion of the European Banking Authority on lending-based crowdfunding

EC, 2015. Crowdfunding: Mapping EU markets and events study

EC, 2016. Crowdfunding in the EU Capital Markets Union, Commission Staff Working Document No. 154

EC, 2017. Identifying market and regulatory obstacles to crossborder development of crowdfunding. This study was led by the European Crowdfunding Network AISBL together with Osborne Clarke, Germany.

EC, 2018a. FinTech: Commission takes action for a more competitive and innovative financial market, Brussels, 8 March 2018.

EC, 2018b. Proposal for a regulation of the European parliament and of the council on European crowdfunding service providers for business

ESMA, 2014. Position paper. Crowdfunding

Everett, C. R. 2015. Group membership, relationship banking and loan default risk: The case of online social lending, Banking and Finance Review 7(2).

EY, 2017. Unleashing the potential of FinTech in banking, report, September.

Federal Reserve, 2017. Small Business Credit Survey: Report on Employer Firms

Freedman, S. and Jin, G., 2011. Learning by Doing with Asymmetric Information : Evidence from Proper.com. NBER Working Paper $n^{\circ} 16855$. 
FCA, 2016. Interim feedback to the call for input to the post-implementation review of the FCA's crowdfunding rules, Feedback statement FS16/13

Freixas X. and J.-C. Rochet, 2008. Microeconomics of banking, MIT, 2nd ed.

Havrylchyk, O. and M. Verdier, 2018. The financial intermediation role of the P2P lending platforms, Comparative Economic Systems 60 (1), 115-130.

Havrylchyk, O., C. Mariotto, T. Rahim and M. Verdier, 2018. What drives the expansion of the peer-topeer lending?, http://papers.ssrn.com/sol3/papers.cfm?abstract_id=2841316.

Hildebrand, T., M. Puri and J. Rocholl, 2016. Skin in the Game: Incentives in Crowdfunding, Management Science 63 (3), 587 - 608.

Hughes, J. P. \& Mester, L. J., 2013. Who said large banks don't experience scale economies? Evidence from a risk-return-driven cost function, Journal of Financial Intermediation 22(4), 559-585.

Irish Department of Finance, 2018. Feedback Paper on the Regulation of Crowdfunding in Ireland. Following on from public consultation

Iyer, R., A. I. Khwaja, E. F. P. Luttmer and K. Shue, 2016. Screening Peers Softly: Inferring the Quality of Small Borrowers, Management Science 62:6, 1554-1577

Keys, B. T. Mukherjee, A. Seru and V. Vig, 2010. Did securitization lead to lax screening? Evidence from subprime loans, The Quarterly Journal of Economics 125 (1), 307-362.

KNF, 2017. Report on the activities of the Special Task Force for Financial Innovation in Poland

Lin, M., Prabhala, N. R., and Viswanathan, S. 2013. Judging Borrowers By The Company They Keep: Friendship Networks and Information Asymmetry in Online Peer-to-Peer Lending. Management Science, 59(1): 17-35.

Lu, Y., Gu, B., Ye, Q., and Sheng, Z. 2012. Social Influence and Defaults in Peer-to-Peer Lending Networks. Conference on Information Systems and Technology (CIST 2012) White Paper.

Manbeck, P., M. Franson and L. Henry, 2017. The regulation of marketplace lending: A Summary of the Principal Issues, March 2017 Update, Chapman and Cutler LLP.

Mester, L., Nakamura, L. and Renault, M., 2007. Transaction accounts and loan monitoring. Review of Financial Studies 20, 529-556.

Mohammadi, A. and K. Shafi, 2016. How Wise Are Crowd? A Comparative Study of Crowd and Institutions in Peer-to-Business Online Lending Markets, Swedish House of Finance Research Paper No. 17-10.

Morse, A., 2015. Peer-to-Peer Crowdfunding: Information and the Potential of discruption in consumer lending. NBER Working Paper No. 20899.

Nash, R. M. and E. Beardsley, 2015. The Future of Finance. The rise of the new Shadow Bank, Goldman Sachs.

Nier, Erlend \& Baumann, Ursel, 2006. "Market discipline, disclosure and moral hazard in banking," Journal of Financial Intermediation, Elsevier, vol. 15(3), pages 332-361, July.

Norden, L. and Weber, M., 2010. Credit line usage, checking account activity, and default risk of bank borrowers. Review of Financial Studies 23, 3665-3699.

Oxera, 2016. The economics of peer-to-peer lending. Prepared for the Peer-to-Peer Finance Association

PeerIQ, 2017. MPL Loan Performance Monitor, December 2017 
Philippon, T., 2016. The FinTech Opportunity. NBER Working Paper n²2476.

Pope, D., and Sydnor, J. 2011. What's in a Picture? Evidence of Discrimination from Prosper.com. Journal of Human Resources, 46(1): 53-92.

Ravina, E. 2012. Love \& Loans: The Effect of Beauty and Personal Characteristics in Credit Markets. Working Paper.

The Economist, 2013. Lenders are turning to social media to assess borrowers; Feb 9th 2013

Pierrakis, Y. and L. Collins, 2013. Banking on each other. Peer-to-peer lending to business: Evidence from Funding Circle, Nesta.

Rahim, T. 2016. Can Peer-to-Peer Platforms Improve Market Outcomes by Controlling Prices?, Working Paper.

Sato, Y., 2014. Opacity in Financial Markets, Review of Financial Studies, 2014, 27, 3502-3546.

Carlin, B., and G. Manso. 2011. Obfuscation, learning, and the evolution of investor sophistication. Review of Financial Studies 24:754-85.

Schich, S. and S. Lindh,2012, Implicit guarantees for bank debt: where do we stand?, OECD Journal: Financial Market Trends, Vol. 2012/1.

Schich, S., 2013. How to reduce implicit bank debt guarantees?: A framework for discussing bank regulatory reform, Journal of Financial Regulation and Compliance, Vol. 21 Issue: 4, pp.308-318

Stracca, L., 2006. Delegated Portfolio Management: A Survey of the Theoretical Literature, Journal of Economic Surveys, Vol. 20, No. 5, pp. 823-848.

Verdier, M., 2016. Les développements récents de la littérature sur les plates-formes, Revue Economique, $\mathrm{N}^{\circ} 67, \mathrm{P} .25-38$.

Wei, Z., and Lin, M. 2016. Auction vs. Posted-Price: Market Mechanism, Lender Behaviors, and Transaction Outcomes in Online Crowd-Funding. Management Science, Forthcoming.

Wiersch, A. M., B. J. Lipman and B.Barkley, 2016. New Insights on Online Lender Applicants from the Small Business Credit Survey, Federal Reserve Bank of Cleveland

UFC-QUE CHOISIR, 2017. Les placement participatifs. Des placements risqués au potentiel moindre que le Livret A ?

Zhang, B., T. Ziegler, K. Garvey, S. Ridler, N. Yerolemou and R. Hao, 2017. Entrenching innovation. 4th UK Alternative Finance Industry Report, Cambridge Centre for Alternative Finance.

Zingales, L. and M. Winter Domínguez, 2017. Cumplo, Stigler Center case no. 2 


\section{Appendixes}

\section{A1. REGULATION OF LENDING-BASED CROWDFUNDING PLATFORMS IN AUSTRIA}

\begin{tabular}{|c|c|}
\hline & Austria \\
\hline $\begin{array}{l}\text { Legal status for } \\
\text { lending-based } \\
\text { crowdfunding } \\
\text { platforms }\end{array}$ & $\begin{array}{l}\text { There is no single legal framework for crowdfunding in Austria. The Alternative Investment Act } \\
\text { (Alternativfinanzierungsgesetz - AltFG) establishes a transparent regulatory framework facilitating } \\
\text { equity-based (crowdinvesting) and lending-based crowdfunding, if certain conditions are met. If } \\
\text { these conditions are not met, crowdfunding is governed by the general regulatory framework, in } \\
\text { particular the Capital Market Act (Kapitalmarktgesetz - KMG). At the moment, an amendment of the } \\
\text { Alternative Investment Act is in the making with the intention to streamline the two existing systems } \\
\text { of the AltFG and the KMG. }\end{array}$ \\
\hline Date of the legislation & Entry into force: 1 September 2015 \\
\hline $\begin{array}{l}\text { Name is the } \\
\text { supervisor }\end{array}$ & The Austrian Ministry for Digital, Business and Enterprise. \\
\hline $\begin{array}{l}\text { Type of loan/debt } \\
\text { security }\end{array}$ & $\begin{array}{l}\text { Bonds and subordinated loans (no unconditional repayment claim). } \\
\text { The same act covers shares, participation rights, and silent partnerships. }\end{array}$ \\
\hline $\begin{array}{l}\text { Minimum capital } \\
\text { requirements }\end{array}$ & No \\
\hline $\begin{array}{l}\text { Automatic } \\
\text { investing }\end{array}$ & No \\
\hline Secondary market & No \\
\hline Clients money & Should rely on the payment institution. \\
\hline Max size of security & $\begin{array}{l}\text { EUR } 1.5 \text { Mio. per emission. However, over a period of seven years, a maximum of EUR } 5 \text { Mio. may } \\
\text { be collected, if no repayments are made in the meantime }\end{array}$ \\
\hline Max invested amount & $\begin{array}{l}5,000 \text { per investor and project (within } 12 \text { months) } \\
\text { Exception: Professional investors or legal persons, issuers who declare that their investment is } \\
\text { limited to } 10 \% \text { of all their capital assets or to the double amount of their monthly income. }\end{array}$ \\
\hline $\begin{array}{l}\text { Disclosure and } \\
\text { warnings }\end{array}$ & $\begin{array}{l}\text { Details regarding the operator of the internet platform: legal form, company, registered office, } \\
\text { information about the owners as well as disclosure of all beneficial owners involved with at least } \\
25 \% \text {, in the case of legal persons with excerpt from the corporate register, objective of the } \\
\text { company, current annual financial statement; the selection criteria applied to projects and the fees } \\
\text { charged; Indication of the nature, frequency and amount of fees paid by investors and issuers. } \\
\text { The information sheet that complies with the terms of the AltFG and the Alternative Financing } \\
\text { Information Regulation (Alternativfinanzierungs-Informationsverordnung - AltF-InfoV). The } \\
\text { information should be checked for coherence, completeness and comprehensibility. The issuer's } \\
\text { business plan, annual financial statement and terms and conditions that apply between the issuer } \\
\text { and the investor }\end{array}$ \\
\hline $\begin{array}{l}\text { Do investors have to } \\
\text { pass a financial } \\
\text { literacy test? }\end{array}$ & No \\
\hline $\begin{array}{l}\text { Business continuity } \\
\text { requirements }\end{array}$ & No \\
\hline $\begin{array}{l}\text { Can platforms invest } \\
\text { in loans/securities } \\
\text { that they facilitate? }\end{array}$ & $\begin{array}{l}\text { The platform itself may only act in the capacity of investor under certain conditions: It is permitted if } \\
\text { it is a minor investment, which is solely intended to facilitate the flow of information between issuers } \\
\text { and investors, and if expressly referred to. }\end{array}$ \\
\hline $\begin{array}{l}\text { Authorization and } \\
\text { professional } \\
\text { requirements }\end{array}$ & There is no particular authorization process for platforms. \\
\hline
\end{tabular}




\section{A2. REGULATION OF LENDING-BASED CROWDFUNDING PLATFORMS IN BELGIUM}

\begin{tabular}{|c|c|}
\hline & Belgium \\
\hline $\begin{array}{l}\text { Legal status for lending- } \\
\text { based crowdfunding } \\
\text { platforms }\end{array}$ & $\begin{array}{l}\text { The Law on Crowdfunding does not distinguish between lending-based and investment-based } \\
\text { crowdfunding. The law defines an Alternative funding platform (Plateforme de financement } \\
\text { alternatif (FR) / alternatieve-financieringsplatform (NL)). The "alternative funding service" is } \\
\text { defined as the "commercialization, through electronic means, of investment instruments issued } \\
\text { by entrepreneurs or investment vehicles. }\end{array}$ \\
\hline Date of the legislation & Entered in force in 2017. \\
\hline Name of the supervisor & The Financial Services and Markets Authority (FSMA) \\
\hline $\begin{array}{l}\text { Type of loan/debt } \\
\text { security }\end{array}$ & Business loan or other alternative funding service \\
\hline $\begin{array}{l}\text { Minimum capital } \\
\text { requirements }\end{array}$ & $\begin{array}{l}\text { There is no minimum capital requirement, but a professional liability insurance of at least } \\
€ 750,000 \text { per claim and insurance year; this amount increases to } € 1.25 \text { million when investment } \\
\text { advice is given or when instruments are issued by an investment vehicle. }\end{array}$ \\
\hline $\begin{array}{l}\text { Automatic lending } \\
\text { allowed? }\end{array}$ & No interdiction \\
\hline $\begin{array}{l}\text { Secondary market } \\
\text { allowed? }\end{array}$ & $\begin{array}{l}\text { A platform could in theory organize a Multilateral Trading Facility, but would need however to be } \\
\text { granted the necessary license to perform that activity (which is a MiFID license) }\end{array}$ \\
\hline Clients' money & Platforms cannot hold client's funds. \\
\hline Provision fund allowed? & Not mentioned in the Law. \\
\hline Max size of loan & $\begin{array}{l}\text { General prospectus rules apply to crowdfunding offers: a prospectus is required for offers of } \\
€ 100,000 \text { or more. However, there exists a crowdfunding exemption for offers below } € 300,000 \text {, } \\
\text { submitted to some conditions, notably that the individual amount that each investor can invest is } \\
\text { limited to } € 5,000 \text {. }\end{array}$ \\
\hline Max invested amount & See above. \\
\hline $\begin{array}{l}\text { Scoring model verified } \\
\text { by the regulator }\end{array}$ & Not mentioned in the Law. \\
\hline Collateral allowed & Not mentioned in the Law. \\
\hline $\begin{array}{l}\text { Access to credit } \\
\text { information sharing } \\
\text { scheme allowed? }\end{array}$ & Not mentioned in the Law. \\
\hline $\begin{array}{l}\text { Disclosure and risk } \\
\text { warnings }\end{array}$ & $\begin{array}{l}\text { Before providing the alternative funding service, platforms must provide the following information } \\
\text { to their clients on a durable support: their identity; their status as well as the name of the } \\
\text { competent authority that granted it; a description of the cost of the service; a description of the } \\
\text { conflicts of interest policy; a description of the rules that apply to the service provision; a } \\
\text { description of the criteria and procedures used to select projects proposed to crowdfunders; the } \\
\text { maximal amount that is tax deductible in case the investment is eligible to the tax-incentive } \\
\text { program; the main characteristics of the investment instruments that are commercialized on the } \\
\text { platforms so as to allow potential investors to assess the nature and risks of those instruments. } \\
\text { There is no obligation to publish returns or default rates. }\end{array}$ \\
\hline $\begin{array}{l}\text { Do lenders have to } \\
\text { pass a financial literacy } \\
\text { test? }\end{array}$ & $\begin{array}{l}\text { Investors are subject to an "appropriateness test" (knowledge and experience). In case platforms } \\
\text { conclude that the investment instruments are not appropriate for the investor, they must warn } \\
\text { him. }\end{array}$ \\
\hline $\begin{array}{l}\text { Business continuity } \\
\text { requirements }\end{array}$ & Yes, notably at IT level. No obligation to have a contract with the third party. \\
\hline $\begin{array}{l}\text { Can platforms invest in } \\
\text { loans/securities that } \\
\text { they facilitate? }\end{array}$ & $\begin{array}{l}\text { Platforms can invest in investment instruments that they commercialize, but must comply with } \\
\text { general conflicts of interest rules. }\end{array}$ \\
\hline $\begin{array}{l}\text { Authorization of } \\
\text { platforms and } \\
\text { professional } \\
\text { requirements for } \\
\text { applicants }\end{array}$ & $\begin{array}{l}\text { The platforms must provide the identity of persons that control them, and those persons must } \\
\text { have the necessary quality in order to ensure a prudent and safe management of the company. } \\
\text { The platforms must have at least two managers, who must be fit and proper. }\end{array}$ \\
\hline
\end{tabular}




\section{A3. REGULATION OF LENDING-BASED CROWDFUNDING PLATFORMS IN FINLAND}

\begin{tabular}{|c|c|}
\hline & Finland \\
\hline $\begin{array}{l}\text { Legal status for lending- } \\
\text { based crowdfunding } \\
\text { platforms }\end{array}$ & $\begin{array}{l}\text { Crowdfunding Act (734/2016) covers both lending-based crowdfunding platforms and } \\
\text { investment-based crowdfunding platforms. }\end{array}$ \\
\hline Date of the legislation & 25.8 .2016 \\
\hline Name of the supervisor & Financial Supervisory Authority \\
\hline Type of loan/debt security & $\begin{array}{l}\text { The bespoken regime covers business loans and bonds. } \\
\text { It also covers equity. }\end{array}$ \\
\hline $\begin{array}{l}\text { Minimum capital } \\
\text { requirements }\end{array}$ & $\begin{array}{l}\text { EUR } 50,000 \text { in equity or professional liability insurance policy, bank guarantee or } \\
\text { other corresponding collateral which the Financial Supervisory Authority deems to } \\
\text { be sufficient. }\end{array}$ \\
\hline Automatic lending allowed? & Not regulated \\
\hline Secondary market allowed? & No \\
\hline Clients' money & $\begin{array}{l}\text { No unauthorized money handling is allowed. The platform has to rely on banking services } \\
\text { (licensed) or payment institutions or they should apply for a registration as a payment } \\
\text { institution. }\end{array}$ \\
\hline Provision fund allowed? & No \\
\hline Max size of loan & No limit \\
\hline Max invested amount & No limit \\
\hline $\begin{array}{l}\text { Scoring model verified by } \\
\text { the regulator }\end{array}$ & No \\
\hline Collateral allowed & No \\
\hline $\begin{array}{l}\text { Access to credit information } \\
\text { sharing scheme allowed? }\end{array}$ & No \\
\hline $\begin{array}{l}\text { Disclosure and risk } \\
\text { warnings }\end{array}$ & $\begin{array}{l}\text { According to Section } 10 \text { of Crowfunding Act, intermediaries must comply with: } \\
\text { 1) According to the provisions of section } 5 \text { of the Act on Investment Services on the duty of } \\
\text { disclosure; the investment firm shall provide to a retail client sufficient information on: } 1 \text { ) the } \\
\text { investment firm and the service provided by it;2) the nature of the types of financial } \\
\text { instruments and other financial products subject to the service and the risks particular } \\
\text { thereto; } 3 \text { ) investment strategies, if suggested, and the risks involved therein;4) the places } \\
\text { where orders will be executed;5) the depositing of client assets and the risks particular } \\
\text { thereto especially in situations where the client assets are deposited with a third party or in a } \\
\text { securities account; } 6 \text { ) the expenses and fees relating to the service. } \\
\text { In addition, according to Section } 11 \text { of Crowfunding Act Duty of disclosure: (1) No false or } \\
\text { misleading information may be given in the marketing of crowdfunding. (2) For the purpose } \\
\text { of a considered assessment of a crowdfunding recipient and the favourability of an offer, the } \\
\text { crowdfunding recipient must disclose true and sufficient information about factors that are } \\
\text { likely to materially influence a company's value or its repayment ability, before starting to } \\
\text { acquire funds. Crowdfunding intermediaries must take care to ensure that crowdfunding } \\
\text { recipients meet the obligation laid down in this subsection.(3) Crowdfunding recipients and } \\
\text { crowdfunding intermediaries have an obligation to release information without delay about } \\
\text { material changes that occur in their economic circumstances and about other factors that } \\
\text { affect the fulfillment of their obligations (4) Notwithstanding the provisions of Chapter } 4 \text {, } \\
\text { section } 3 \text { of the Securities Markets Act, crowdfunding recipients do not need to publish a } \\
\text { prospectus if the securities are offered in Finland and their combined consideration over } 12 \\
\text { months is less than EUR } 5,000,000 \text {. }\end{array}$ \\
\hline $\begin{array}{l}\text { Do lenders have to pass a } \\
\text { financial literacy test? }\end{array}$ & No \\
\hline $\begin{array}{l}\text { Business continuity } \\
\text { requirements }\end{array}$ & No \\
\hline $\begin{array}{l}\text { Can platforms invest in } \\
\text { loans/securities that they } \\
\text { facilitate? }\end{array}$ & Yes \\
\hline $\begin{array}{l}\text { Authorization of platforms } \\
\text { and professional } \\
\text { requirements for applicants }\end{array}$ & $\begin{array}{l}\text { The registration process (for loan based crowfunding and investment-based crowfunding } \\
\text { with other securities than financial instruments) is stated in sections } 3 \text { to } 7 \text { of Crowfunding } \\
\text { Act. }\end{array}$ \\
\hline
\end{tabular}




\section{A4. REGULATION OF LENDING-BASED CROWDFUNDING PLATFORMS IN FRANCE}

\begin{tabular}{|c|c|}
\hline & France \\
\hline $\begin{array}{l}\text { Legal status for lending- } \\
\text { based crowdfunding } \\
\text { platforms }\end{array}$ & $\begin{array}{l}\text { Ordonnance } n^{\circ} 2014-559 \text { has modified the Financial and Monetary code to introduce the legal } \\
\text { status of crowdfunding (financement participative). There are two legal statuses: } \\
\text { IFP: Crowdfunding intermediary (Intermédiaire en financement participatif) for lending-based } \\
\text { crowdfunding platforms } \\
\text { CIP: Crowdfunding advisor (Conseiller en investissement participatif) for investment-based } \\
\text { crowdfunding platforms that include mini-bonds. } \\
\text { Regulation of minibonds was introduced by ordonnance } n^{\circ} 2016-520 \text { ( } 28 \text { april 2016). }\end{array}$ \\
\hline Date of the legislation & 1 November, 2014 \\
\hline Name of the supervisor & $\begin{array}{l}\text { Registered by the ORIAS (the French register of financial intermediaries). There are no reporting } \\
\text { requirements. } \\
\text { Supervision of IFP is done via controls by the ACPR. The equivalent of one man per year is } \\
\text { devoted to controls. } \\
\text { Supervision of CIP is done by the AMF. }\end{array}$ \\
\hline $\begin{array}{l}\text { Type of loan/debt } \\
\text { security }\end{array}$ & $\begin{array}{l}\text { IFP: Business loans; } \\
\text { CIP: Unlisted securities (bonds with fixed rates and since 2016, bonds convertible into shares) } \\
\text { and minibonds (a subcategory of « bons de caisse » dedicated to crowdfunding). }\end{array}$ \\
\hline $\begin{array}{l}\text { Minimum capital } \\
\text { requirements }\end{array}$ & $\begin{array}{l}\text { No, but professional liability insurance policy covering } 250000 \text { euros per event and } 500000 \\
\text { euros per year for IFP and } 400000 \text { euros per event and } 800000 \text { euros per year for CIP. }\end{array}$ \\
\hline $\begin{array}{l}\text { Automatic lending } \\
\text { allowed? }\end{array}$ & $\begin{array}{l}\text { According to the Treasury, it has not been foreseen but one platform with the CIP status has an } \\
\text { automatic bidding function. }\end{array}$ \\
\hline $\begin{array}{l}\text { Secondary market } \\
\text { allowed? }\end{array}$ & $\begin{array}{l}\text { It has not been foreseen for the IFP, but not excluded for CIP. It is even envisage by the } \\
\text { ordonnance from } 29 \text { of April } 2016 \text {, that allows trading of minibonds on the blockchain. }\end{array}$ \\
\hline Clients' money & $\begin{array}{l}\text { Neither IFP nor CIP platforms can receive any money, unless they obtain the status of agent } \\
\text { providing payment services. A limited payment institution was put in place especially for IFP, but } \\
\text { none of the IFP has asked to have this status. }\end{array}$ \\
\hline Provision fund allowed? & Not foreseen by the ordonnance, but some platforms have put it in place. \\
\hline Max size of loan & $\begin{array}{l}\text { IFP: } 1 \text { mln Euros } \\
\text { CIP: } 2.5 \text { million, with the exception if security amounts to more than } 50 \% \text { of issuer's capital then } \\
\text { the limit is } 1 \text { million. Minibonds are limited to } 2.5 \mathrm{mln} \text { Euros. Announcement to increase the } \\
\text { threshold to } 8 \text { mln Euros (loi Pacte has not yet been voted at the moment of the publication of } \\
\text { this working paper) }\end{array}$ \\
\hline Max invested amount & $\begin{array}{l}\text { IFP: } 2000 \text { Euros per loan } \\
\text { CIP: no limit }\end{array}$ \\
\hline $\begin{array}{l}\text { Scoring model verified } \\
\text { by the regulator }\end{array}$ & No \\
\hline Collateral allowed & Not foreseen \\
\hline $\begin{array}{l}\text { Access to credit } \\
\text { information sharing } \\
\text { scheme allowed? }\end{array}$ & 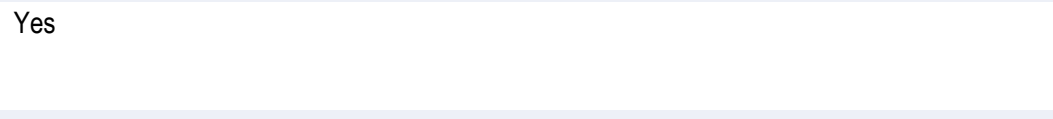 \\
\hline $\begin{array}{l}\text { Disclosure and risk } \\
\text { warnings }\end{array}$ & $\begin{array}{l}\text { IFP platforms must disclose to users:Registration number of the platform from ORIAS; Generals } \\
\text { terms and conditions; Charges and fees; Eligibility conditions and screening criteria; The main } \\
\text { features of the loans; Each project and fund seekers; Default rate and credit risk for the lender; } \\
\text { The risk for borrower to have a high-income debt and consequences in case of default; The } \\
\text { accountability for each borrower and lender in case of fund seeker default; Loans duration; } \\
\text { Recovery process; Provide a test of eligibility for lenders } \\
\text { CIP platforms must disclose their activity, their project, the characteristics of the existing } \\
\text { securities and securities to issue, the exit conditions; Income statement and financial information; } \\
\text { Share of capital hold by executive members; The financial, voting and information rights; } \\
\text { Securities liquidity; The conditions of access ; The fees and charge. } \\
\text { ACPR has provided the exact formula for the calculation of default rates. }\end{array}$ \\
\hline $\begin{array}{l}\text { Do lenders have to pass } \\
\text { a financial literacy test? }\end{array}$ & $\begin{array}{l}\text { IFP: Platforms have to provide to their retail investors a tool which assesse their financial } \\
\text { capacity. } \\
\text { CIP: There is a progress-access website in which investors are asked questions about their } \\
\text { financial skills and income. }\end{array}$ \\
\hline
\end{tabular}


Business continuity $\quad$ Yes, with an explicit contract with the payment services provider.

requirements

Can platforms invest in No

loans/securities that

they facilitate?

Authorization of

platforms and

professional

requirements for

applicants

IFP: The applicant must fulfill certain conditions:

The platform managers have to follow regulatory conditions of good repute and professional competences; have a professional liability insurance policy; to comply with the rules relating to the fight against money laundering and financing terrorism; carry out intermediary project activity as their regular activity, and cannot combine the IFP status with IOBSP (banking activity and payment services intermediary), IAS (insurance intermediary) and CIF (investment services provider). However the IFP status can be combine with the CIP status.

CIP: The platform managers have to follow regulatory conditions of good repute and professional competences, have a professional liability insurance policy, to be a membership of an industry group related by the AMF, to comply with the rules relating to the fight against money laundering and financing terrorism. 


\section{A5. REGULATION OF LENDING-BASED CROWDFUNDING PLATFORMS IN GERMANY}

\begin{tabular}{|c|c|}
\hline & Germany \\
\hline $\begin{array}{l}\text { Legal status for } \\
\text { lending-based } \\
\text { crowdfunding } \\
\text { platforms }\end{array}$ & $\begin{array}{l}\text { No defined status for lending-based crowdfunding platforms. Investment-based crowdfunding } \\
\text { platform that allow debt instruments act as investment intermediaries (Finanzanlagenvermittler) } \\
\text { pursuant to section } 34 \mathrm{f} \text { of the German Commercial Code (Gewerbeordnung - GewO). }\end{array}$ \\
\hline Date of the legislation & $\begin{array}{l}10 \text { July } 2015 \text { (entry into force of the Retail Investor Protection Act of } 3 \text { July } 2015 \\
\text { (Kleinanlegerschutzgesetz vom 3. Juli 2015)) }\end{array}$ \\
\hline $\begin{array}{l}\text { Name is the } \\
\text { supervisor }\end{array}$ & $\begin{array}{l}\text { If platforms are authorized as investment intermediaries (Finanzanlagenvermittler), the competent } \\
\text { authorities of the federal states (Länder), usually the trade office (Gewerbeamt) or the Chamber of } \\
\text { Industry and Commerce (Industrie- und Handelskammer (IHK)). }\end{array}$ \\
\hline $\begin{array}{l}\text { Type of loan/debt } \\
\text { security }\end{array}$ & $\begin{array}{l}\text { Profit-participating loans, subordinated loans - please note that these loans do not fall under the } \\
\text { definition of "transferable securities" of MiFID II and are thus covered by the bespoke German } \\
\text { crowdinvesting regime introduced by the Retail Investor Protection Act of } 3 \text { July } 2015 \\
\text { (Kleinanlegerschutzgesetz vom 3. Juli 2015). }\end{array}$ \\
\hline $\begin{array}{l}\text { Minimum capital } \\
\text { requirements }\end{array}$ & $\begin{array}{l}\text { No minimum capital requirements for platforms with a commercial license, but they must take out } \\
\text { professional liability insurance in accordance with the Financial Investment Brokerage Ordinance } \\
\text { (Finanzanlagenvermittlungs-verordnung) which stipulates certain minimum sums insured which are } \\
\text { periodically adjusted. Since } 15 \text { January } 2018, \text { the minimum sum insured amounts to EUR } \\
1,276,000 \text { per insured event and to EUR } 1,919,000 \text { as regards all insured events in one year. }\end{array}$ \\
\hline Automatic investing & $?$ \\
\hline Secondary market & $\begin{array}{l}\text { Platforms that would like to establish secondary markets need an authorization as a financial } \\
\text { services institution pursuant to the German Banking Act (Kreditwesengesetz - KWG), if they } \\
\text { operate a multilateral trading facility in relation to profit participating/subordinated loans. }\end{array}$ \\
\hline Max size of security & $€ 2.5$ million, if exemption from the full prospectus requirement is relied on. \\
\hline Max invested amount & $\begin{array}{l}\text { If the investor has freely available assets of at least } € 100,000 \text { : up to } € 10,000 \text { in an issue. } \\
\text { If the investor does not have freely available assets of at least } € 100,000 \text { : twice the investor's } \\
\text { monthly income, but in any case not more than } € 10,000 \\
\text { In all other cases (particularly if the investor does not provide a statement on assets and income): } \\
€ 1,000 \\
\text { No limits for corporate entities. }\end{array}$ \\
\hline $\begin{array}{l}\text { Disclosure and } \\
\text { warnings }\end{array}$ & $\begin{array}{l}\text { Issuer must prepare an investment information sheet (Vermögensanlagen-Informationsblatt, VIB) } \\
\text { and submit it to BaFin for approval. VIB must: present essential information about the investment; } \\
\text { contain a notice that there is no prospectus approved by BaFin; contain a notice that further } \\
\text { information may be requested from offeror or issuer; warn about the risks. Investors must confirm } \\
\text { that they have taken note (signature or equivalent). Civil liability of offeror if VIB is misleading or } \\
\text { inaccurate. } \\
\text { Issuer must comply with rules on marketing of investments (warning of risks). }\end{array}$ \\
\hline $\begin{array}{l}\text { Do investors have to } \\
\text { pass a financial } \\
\text { literacy test? }\end{array}$ & No. \\
\hline $\begin{array}{l}\text { Business continuity } \\
\text { requirements }\end{array}$ & No \\
\hline $\begin{array}{l}\text { Can platforms invest } \\
\text { in loans/securities } \\
\text { that they facilitate? }\end{array}$ & No \\
\hline $\begin{array}{l}\text { Authorization and } \\
\text { professional } \\
\text { requirements }\end{array}$ & $\begin{array}{l}\text { Professional liability insurance, no disorderly financial situation, reliability, expertise shown by } \\
\text { passing exam conducted by the Chamber of Industry and Commerce. }\end{array}$ \\
\hline
\end{tabular}




\section{A6. REGULATION OF LENDING-BASED CROWDFUNDING PLATFORMS IN ISRAEL}

\begin{tabular}{|c|c|}
\hline & Israel \\
\hline $\begin{array}{l}\text { Legal status for } \\
\text { lending-based } \\
\text { crowdfunding } \\
\text { platforms }\end{array}$ & $\begin{array}{l}\text { In Israel, there are two sets of laws that apply to raising funds in a mechanism of crowdfunding: } \\
\text { 1. The Securities Law and the regulations under it regulate most of the crowdfunding activity carried out } \\
\text { by corporations, including selling of corporate shares, the raising of debt of a specific corporation, and } \\
\text { the raising of corporate debt by spreading risk in an investment portfolio with debt volumes of over NIS } \\
1 \text { million. The Israel Securities Authority (ISA) regulates this activity and these platforms. } \\
2 \text {. The Control of Financial Services Law relates to the regulation of the financing of mass loans by } \\
\text { individuals and corporations up to NIS } 1 \text { million. The Capital Markets Insurance and Savings Authority } \\
\text { (CMISA) regulates this activity. Most platforms fall under this regulation. } \\
\text { Responses also refer to the draft amendment to the Securities Regulations regarding the subject of } \\
\text { crowdfunding in the model of P2B (peer to business) approved by the Finance Committee in November } \\
2017 \text { and awaiting approval by the Minister of Finance, according to which the platform } \\
\text { distributes loan funds between various loans. }\end{array}$ \\
\hline $\begin{array}{l}\text { Date of the } \\
\text { legislation }\end{array}$ & $\begin{array}{l}\text { The Control of Financial Services Law was legislated in 2016. The section dealing with credit } \\
\text { intermediation systems was enacted on August 6, } 2017 \text { and came into effect on February 1, } 2018 \text {. } \\
\text { The Securities Regulations (Offer of Securities through Offer Coordinator), } 5767 \text { - } 2017 \text { went into effect } \\
\text { on December 26, 2017. }\end{array}$ \\
\hline $\begin{array}{l}\text { Name of the } \\
\text { supervisor }\end{array}$ & $\begin{array}{l}\text { CMISA supervises lending-based crowdfunding platforms with loans up to NIS } 1 \text { million. There are } 3 \\
\text { people who are responsible for the supervision and in the near future CMISA intends to recruit } \\
\text { additional employees to supervise crowdfunding platforms. } \\
\text { With regard to security-based crowdfunding platforms, the law stipulates that a company that raises } \\
\text { over NIS } 1 \text { million through mass mobilization platforms will be regulated by the ISA. The unit } \\
\text { responsible for this is the unit for financing small and medium businesses in the corporate department. } \\
\text { To date, the unit includes three lawyers. }\end{array}$ \\
\hline $\begin{array}{l}\text { Type of loan/debt } \\
\text { security }\end{array}$ & $\begin{array}{l}\text { CMISA: no restriction (consumer, housing, business, etc.) } \\
\text { ISA: Business loans, debt securities. }\end{array}$ \\
\hline $\begin{array}{l}\text { Minimum capital } \\
\text { requirements }\end{array}$ & $\begin{array}{l}\text { CMISA: According to the first addition to the law, credit-brokerage platforms must have equity of NIS } \\
100,000 \text {. The Supervisor has the power to order additional shareholders' equity, if required, and to } \\
\text { provide instructions regarding liquidity requirements. } \\
\text { ISA : There is no minimum capital requirement. At the same time, offer coordinators are required by } \\
\text { virtue of Regulation } 2 \text { (5) of the Offer Coordinator Regulations to deposit at least NIS } 100,000 \text { in a } \\
\text { deposit with a bank or stock exchange member in trust. }\end{array}$ \\
\hline $\begin{array}{l}\text { Automatic lending } \\
\text { allowed? }\end{array}$ & CMISA: Yes \\
\hline $\begin{array}{l}\text { Secondary } \\
\text { market allowed? }\end{array}$ & $\begin{array}{l}\text { CMISA: Yes } \\
\text { ISA : There is no possibility of establishing a secondary market that will be exempt from the obligation } \\
\text { to publish a prospectus. The offering of securities of companies to more than } 35 \text { investors by their } \\
\text { holders will require the publication of a prospectus and the possibility of trading them through the } \\
\text { platform will oblige the platform to receive a stock exchange management license under Section } 45 \text { of } \\
\text { the Securities Law. }\end{array}$ \\
\hline Clients' money & Can be hold by the platform, but in a separate trust account. \\
\hline $\begin{array}{l}\text { Provision fund } \\
\text { allowed? }\end{array}$ & Not clear \\
\hline $\begin{array}{l}\text { Max size of } \\
\text { loan/debt security }\end{array}$ & $\begin{array}{l}\text { CMISA: NIS } 1 \text { million } \\
\text { ISA: NIS } 6 \text { million per year. NIS } 4 \text { million without any conditions. NIS 4-6 million depends on the } \\
\text { external approvals of the Chief Scientist or the Small Business Agency or the presence of a "leading" } \\
\text { investor who is experienced, not related to the company and invests at least } 10 \% \text { of the total amount } \\
\text { raised by the offering company. The latter is subject to the relevant provisions in the Offer Coordinator } \\
\text { Regulations. }\end{array}$ \\
\hline $\begin{array}{l}\text { Max invested } \\
\text { amount }\end{array}$ & $\begin{array}{l}\text { CMISA: No limit } \\
\text { ISA: the limit is NIS } 10,000 \text { for investment in a particular company and NIS } 20,000 \text { for investment in a } \\
\text { crowdfunding mechanism under the Securities Law. These amounts can be increased relative to the } \\
\text { extent of the investor's income to } 5 \% \text { of his annual income and no more than a maximum amount of } \\
\text { NIS } 100,000 \text { per year. } \\
\text { Investors who meet the definition of "sophisticated investor" or "qualified customer" are not subject to } \\
\text { restrictions on investment amounts. }\end{array}$ \\
\hline
\end{tabular}




\begin{tabular}{|c|c|}
\hline & $\begin{array}{l}\text { Upon completion and entry into effect of the regulation of debt raising in the P2B model in which the } \\
\text { platform distributes loan funds between different loans, the maximum investment amounts on these } \\
\text { platforms will be as follows: } \\
\text { As long as the loan portfolio of the investor is divided into no less than } 20 \text { loans, so that no loan } \\
\text { exceeds } 5 \% \text { of the total investment portfolio - the maximum investment amount will be NIS } 50,000 \text { per } \\
\text { year in crowdfunding investments under the Securities Law. }\end{array}$ \\
\hline $\begin{array}{l}\text { Scoring model } \\
\text { verified by the } \\
\text { regulator }\end{array}$ & CMISA: No \\
\hline Collateral allowed & $\begin{array}{l}\text { CMISA: Yes } \\
\text { ISA: Yes }\end{array}$ \\
\hline $\begin{array}{l}\text { Access to credit } \\
\text { information } \\
\text { sharing scheme } \\
\text { allowed? }\end{array}$ & $\begin{array}{l}\text { CMISA: The platforms are entitled to receive information and a platform that reaches more than NIS } 250 \\
\text { million will also need to provide information to the database. } \\
\text { ISA: No }\end{array}$ \\
\hline $\begin{array}{l}\text { Disclosure and } \\
\text { risk warnings }\end{array}$ & $\begin{array}{l}\text { CMISA: The licensee has to act in favor of the lenders in trust and diligence. The level of dispersion } \\
\text { and rate of return, the methods of operation of the system, the fees charged by the platform, the rate of } \\
\text { credit of all borrowers, the rate of unpaid credit for each level of risk, and the rate of return. The } \\
\text { platform should publish data on yield, billing and lost money. } \\
\text { ISA:An offer coordinator is required to publish extensive disclosures about himself and about the bids of } \\
\text { the recruiting companies. The full information required is detailed in the regulations, which include, inter } \\
\text { alia, the following disclosure details: The valuation method used in order to provide a rating for the } \\
\text { securities offered (as far as there is a rating mechanism); Details of the offer, including the period of } \\
\text { submission, number of securities offered, percentage of capital, the results of the offer and dates of the } \\
\text { transfer of funds; Information and warnings as prescribed in the regulations; Information regarding } \\
\text { assessment methods of the rating; Information regarding procedures for keeping documents, } \\
\text { documentation, information security and ensuring continuity of activity; Information regarding the } \\
\text { manner of determination of the payment amount collected by the offer coordinator; The structure of } \\
\text { holdings of controlling shareholders and officers in the offer coordinator; Means of communication with } \\
\text { the offer coordinator; Warnings regarding fraudulent offers; Any material interest to the investor; } \\
\text { Procedures and measures taken by the offer coordinator to review the proposal and comply with the } \\
\text { requirements of the law; Fraud prevention procedures; Details of officers; Board structure; Criteria for } \\
\text { proposals selection to be published. } \\
\text { According to the draft regulations awaiting approval by the Minister of Finance, P2B platforms will be } \\
\text { required to publish average rates of unpaid debts due by companies for a full 5-year period, as well as } \\
\text { the effective yield that corporate bonds offer in the last } 12 \text { months, compared to the forecasts published } \\
\text { in the past. No formulas were specified. }\end{array}$ \\
\hline $\begin{array}{l}\text { Do lenders have } \\
\text { to pass a financial } \\
\text { literacy test? }\end{array}$ & No \\
\hline $\begin{array}{l}\text { Business } \\
\text { continuity } \\
\text { requirements }\end{array}$ & Yes \\
\hline $\begin{array}{l}\text { Can platforms } \\
\text { invest in } \\
\text { loans/securities } \\
\text { that they facilitate } \\
\text { ? }\end{array}$ & $\begin{array}{l}\text { CMISA: The law prohibits this unless the Supervisor expressly permits it. The additional legal } \\
\text { arrangement that is necessary is in a circular under the authority of the Supervisor that sets the rules } \\
\text { for investment from nostro funds. } \\
\text { ISA : The platform may invest / lend in companies that raise capital and debt through them. }\end{array}$ \\
\hline $\begin{array}{l}\text { Authorization of } \\
\text { platforms and } \\
\text { professional } \\
\text { requirements for } \\
\text { applicants }\end{array}$ & $\begin{array}{l}\text { CMISA: The authorization process is a long one - attached to the licensing process link } \\
\text { http://www.mof.gov.il/hon/ArrangedFinancialServices/Pages/Regulation_Drafts.aspx } \\
\text { ISA :Regulation } 2 \text { establishes the conditions for the registration of an offer coordinator in the register of } \\
\text { coordinators: The Company is required to be a company under the Companies Law, with the technical } \\
\text { expertise and means to act as a offer coordinator (including a website, recruiting a person with } \\
\text { expertise in the field, compliance with information security standards, etc.) which includes at least one } \\
\text { third of independent directors, insurance, deposits of NIS } 100,000 \text {, compliance with the reliability test of } \\
\text { officers and controlling shareholders (there is no requirement for a minimum level of education or } \\
\text { experience, and there is an examination of economic crimes, economic failures, etc.). }\end{array}$ \\
\hline
\end{tabular}




\section{A7. REGULATION OF LENDING-BASED CROWDFUNDING PLATFORMS IN MEXICO}

\begin{tabular}{|c|c|}
\hline & Mexico \\
\hline $\begin{array}{l}\text { Legal status for lending-based } \\
\text { crowdfunding platforms }\end{array}$ & $\begin{array}{l}\text { The law that regulates Financial Technology Platforms (FinTech Law) establishes the } \\
\text { status of Financial Technological Institutions (Instituciones de Tecnología Financiera, } \\
\text { ITFs), which includes crowdfunding institutions (instituciones de financiamiento colectivo) }\end{array}$ \\
\hline Date of the legislation & Approved March 1st, 2017. \\
\hline Name of the supervisor & $\begin{array}{l}\text { National Banking and Securities Commission, the Central Bank of Mexico, and the } \\
\text { Ministry of Finance. }\end{array}$ \\
\hline Type of loan/debt security & The FinTech Law does not mention any specific type of loan/securities. \\
\hline Minimum capital requirements & $\begin{array}{l}\text { The FinTech Law states that crowdfunding platforms will be subject to capital } \\
\text { requirements. These requirements will be determined in the secondary regulation. }\end{array}$ \\
\hline Automatic lending allowed? & The FinTech Law proposal does not consider this. \\
\hline Secondary market allowed? & Yes \\
\hline Clients' money & $\begin{array}{l}\text { Crowdfunding platforms are obliged to keep their clients' deposits separated from their } \\
\text { own resources; moreover, clients' resources have to be client-tagged. }\end{array}$ \\
\hline Provision fund allowed? & This kind of activity may be authorized by the Ministry of Finance. \\
\hline Max size of loan & Will be determined by the CNBV in the secondary regulation. \\
\hline Max invested amount & Will be determined by the CNBV in the secondary regulation. \\
\hline $\begin{array}{l}\text { Scoring model verified by the } \\
\text { regulator }\end{array}$ & If applicable, it will be determined in the secondary regulation. \\
\hline Collateral allowed & Yes \\
\hline $\begin{array}{l}\text { Access to credit information } \\
\text { sharing scheme allowed? }\end{array}$ & Yes \\
\hline Disclosure and risk warnings & $\begin{array}{l}\text { Selection criteria used to determine which projects to fund, select information on the } \\
\text { project to be funded, as well as if the project has been published before in other } \\
\text { crowdfunding platform. } \\
\text { Inform potential clients of the risks associated with their business model (including } \\
\text { general performance indicators). } \\
\text { Platforms must explicitly state that the federal government will not take responsibility or } \\
\text { guarantee ITF's operations with the investors' funds. } \\
\text { More in the secondary regulation. }\end{array}$ \\
\hline $\begin{array}{l}\text { Do lenders have to pass a } \\
\text { financial literacy test? }\end{array}$ & Will be determined in the secondary regulation. \\
\hline $\begin{array}{l}\text { Business continuity } \\
\text { requirements }\end{array}$ & No \\
\hline $\begin{array}{l}\text { Can platforms invest in } \\
\text { loans/securities that they } \\
\text { facilitate? }\end{array}$ & $\begin{array}{l}\text { Yes, a "skin-in-the-game" provision is considered in order to make platforms invest in } \\
\text { their own crowdfunded projects. }\end{array}$ \\
\hline $\begin{array}{l}\text { Authorization of platforms and } \\
\text { professional requirements for } \\
\text { applicants }\end{array}$ & $\begin{array}{l}\text { People interested in operate as a crowdfunding platform will need to apply for the } \\
\text { authorization of the CNBV, who will grant the authorization following a prior a resolution } \\
\text { from an inter-agency Committee. } \\
\text { The Committee will be integrated by } 6 \text { members ( } 2 \text { from the Ministry of Finance, } 2 \text { from } \\
\text { the Central Bank and } 2 \text { from the CNBV). In order to get the authorization, it is required at } \\
\text { least one positive vote from each authority represented on the Committee. } \\
\text { The platforms' founders and/or directors must prove their honorability and satisfactory } \\
\text { credit business scores to the Committee; this mechanism will be further refined in the } \\
\text { secondary regulation. }\end{array}$ \\
\hline
\end{tabular}




\section{A8. REGULATION OF LENDING-BASED CROWDFUNDING PLATFORMS IN PORTUGAL}

\begin{tabular}{|c|c|}
\hline & Portugal \\
\hline $\begin{array}{l}\text { Legal status for lending- } \\
\text { based crowdfunding } \\
\text { platforms }\end{array}$ & $\begin{array}{l}\text { The legal framework for Crowdfunding is provided by Law no. 102/2015, of } 24 \text { August 2015. Law } \\
\text { no. } 3 / 2018 \text {, of } 9 \text { February } 2018 \text { establishes the sanctions applicable to the infringement of the } \\
\text { crowdfunding rules. } \\
\text { This Law covers both lending-based crowdfunding platforms and investment-based } \\
\text { crowdfunding platforms. } \\
\text { The crowdfunding platform itself is not a legal entity separated from the entity managing the } \\
\text { platform which is the entity relevant for all legal purposes. The platform itself constitutes a } \\
\text { "brand" rather than a legal entity. The entity managing a crowdfunding platform must be a legal } \\
\text { person or an individual limited liability establishment. }\end{array}$ \\
\hline Date of the legislation & 2015. The legislation entered into force in February, 2018. \\
\hline Name of the supervisor & CMVM. This currently involves two persons. \\
\hline $\begin{array}{l}\text { Type of loan/debt } \\
\text { security }\end{array}$ & $\begin{array}{l}\text { There is no limitation as to the kind of loans or securities that can be made available by means of } \\
\text { crowdfunding platforms. }\end{array}$ \\
\hline $\begin{array}{l}\text { Minimum capital } \\
\text { requirements }\end{array}$ & $\begin{array}{l}\text { The entities managing crowdfunding platforms must have (1) a minimum share capital of EUR } \\
50,000 \text { or (2) a liability insurance for this specific activity or any equivalent warranty covering } \\
\text { EUR } 1,000.000 \text { per event and, globally, EUR } 1,500.000 \text { for events occurred within periods of one } \\
\text { year or (3) a mix of both that grants the investors the same type of protection and is accepted by } \\
\text { CMVM. }\end{array}$ \\
\hline $\begin{array}{l}\text { Automatic lending } \\
\text { allowed? }\end{array}$ & No \\
\hline $\begin{array}{l}\text { Secondary market } \\
\text { allowed? }\end{array}$ & There is no legal provision preventing this. \\
\hline Provision fund allowed? & There is no legal provision covering this subject matter. \\
\hline Max size of loan & $\begin{array}{l}\text { Maximum amounts applicable are EUR } 1,000.000 \text { per year and per project and EUR } 5,000.000 \text { if } \\
\text { the offer is limited to legal persons, professional investors or individuals with an annual income } \\
\text { equal or higher than } € 70,000 \text {. }\end{array}$ \\
\hline Max invested amount & $\begin{array}{l}\text { Individuals with an annual income inferior to } € 70,000 \text {. are subject to maximum investment limits : } \\
€ 3,000.00 \text { per offer; and } \\
€ 10,000.00 \text { in total crowdfunding investments during the period of } 12 \text { months. }\end{array}$ \\
\hline $\begin{array}{l}\text { Scoring model verified } \\
\text { by the regulator }\end{array}$ & Risk models of platforms are being studied by the CMVM for supervision purposes only. \\
\hline Collateral allowed & The is no legal provision for this. The answer is likely negative. \\
\hline $\begin{array}{l}\text { Access to credit } \\
\text { information sharing } \\
\text { scheme allowed? }\end{array}$ & No \\
\hline $\begin{array}{l}\text { Disclosure and risk } \\
\text { warnings }\end{array}$ & $\begin{array}{l}\text { All beneficiaries of crowdfunding are required to provide the platform with the following } \\
\text { information to be made available online to investors: (1) Information on the identification of the } \\
\text { beneficiaries of crowdfunding: name, legal nature, contacts, address, identity of the members of } \\
\text { the board. (2) In respect of each offer: (a) the description of the activity or product to be financed, } \\
\text { and the purposes of the financing to be raised; (b) the amount and term for the collection; (c) the } \\
\text { price of the values of each unit to be subscribed or the form of determination of this price. The } \\
\text { information provided to investors must be complete, true, current, clear, objective and lawful, } \\
\text { allowing its recipients to form sound judgments about the offer and the beneficiary of the } \\
\text { investment. } \\
\text { Beneficiaries of crowdfunding in the form of capital or loan financing must also communicate to } \\
\text { the platform, for the purpose of informing investors (making it available online) and the CMVM: } \\
\text { (1) All relevant financial information on the beneficiary entity, on compliance with its tax } \\
\text { obligations and on its capital structure. (2) All relevant information about the projects to be } \\
\text { financed, including the associated risks, adequate and proportional to the amount of funding to } \\
\text { be raised, in order to ensure the informed nature of the investment option. (3) Submit annually to } \\
\text { the CMVM and to the platforms with which they maintain a relationship in the framework of this } \\
\text { law their activity reports, to be available for consultation by investors. (4) All relevant information } \\
\text { to guarantee that investors make an informed decision, including: } \\
\text { Information about their previous registration with the CMVM for the purposes of managing the } \\
\text { crowdfunding in the form of capital or loan financing electronic platform; }\end{array}$ \\
\hline
\end{tabular}


Do lenders have to pass a financial literacy test? Business continuity requirements

Can platforms invest in loans/securities that they facilitate?

Authorization of platforms and professional requirements for applicants
Prior information on each offer, submitting a document containing the "key information for investors in crowdfunding investment" with all information necessary for the investor to make an informed decision. This document must contain: The complete identification of the beneficiary; In the case of legal persons, if available, balance sheet and management report of the beneficiary for the immediately preceding financial year; The essential characteristics of the activity or product concerned which enables investors to understand the nature and risks inherent in the product or activity to be financed; The costs and charges associated with the activity or product to be financed, as well as a brief substantiated description of the profitability expectations of the amounts invested; Details of the processing of the offer; The deadline for revocation of the acceptance by the recipients of the offer, when applicable; The timing and manner for the transfer of the amounts raised, in particular the subscription mechanisms, and also for the refund of the amounts invested if there is a collection higher than the amounts provided or if the amounts indicated are not raised and the to provide for the possibility of changing conditions under the rules of the applicable legal regime; Warning about the risk of partial or total loss of the amounts invested; Warning as to the risk of not verifying the estimated profitability of the amounts invested; Warning regarding liquidity risk or lack of secondary market for financial instruments or credits subscribed by investors; Warning that the products and activities to be financed through collaborative financing are not subject to authorisation or supervision by the CMVM or by any other financial supervisory authority, nor do these entities approve the information made available on them; Warning that the investment is not covered by the Investor Compensation Scheme unless it is derived from financial intermediation and verified the assumptions of its application; Warning that the capital invested is not guaranteed under the deposit guarantee fund; Warning that, in the case of issuance of financial instruments, the issue is not subject to CMVM supervision, the CMVM does not approve the information made available through the key information document; Warning that, in the case of loans, this activity is not supervised by Bank of Portugal and it does not approve the information made available through the key information document; Applicable tax regime;

Information on current offers including identification of the beneficiary, crowdfunding form, deadline, rate of remuneration, total amount of the offer, percentage of the amount raised, any credit ratings and guarantees provided, and any other materially relevant information on the terms and conditions of such operations;

Historical information on the projects financed, including the number of projects and respective amounts, broken down by type of crowdfunding and the situation in which the financing is found (financing not due, financing repaid on time and financing not repaid within the term), indicating the average rate of return and the average term of the loans;

Pricing;

Information on investor protection procedures that should be adopted in the event of insolvency, cessation of activity and prolonged inactivity by the managing entity of the crowdfunding electronic platform.

No

Yes

No

The request includes (i) data on the platform - i.e. on the entity managing the platform, (ii) identification of the members of the board of directors, including data on education, experience and repute, (iii) identification of the persons / entities that control the platform or hold qualifying holdings, including data on experience and repute, (iv) accounts of the last three financial years, (v) business plan and description of the structure of the organization as well as of the human and technical support, (vi) business model, including description of the procedures regarding financial flows and/or subscription of securities, (vii) internal policies and procedures of the entity, namely on anti-money laundering (viii) date established for the beginning of operations. After receiving the request for registration and any additional information from the platform CMVM has 30 business days to take a decision and to grant the registration. 


\section{A9. REGULATION OF LENDING-BASED CROWDFUNDING PLATFORMS IN}

\section{THE UK}

\begin{tabular}{|c|c|}
\hline & UK \\
\hline $\begin{array}{l}\text { Legal status for } \\
\text { lending-based } \\
\text { crowdfunding } \\
\text { platforms }\end{array}$ & $\begin{array}{l}\text { The UK government brought peer-to-peer platforms into the scope of regulation by creating a } \\
\text { bespoke regulated activity under the Financial Services and Markets Act } 2000 \text {. } \\
\text { This does not cover investment or debt-based crowdfunding which is typically regulated under the } \\
\text { Markets in Financial Instruments Directive (MiFID) }\end{array}$ \\
\hline $\begin{array}{l}\text { Date of the } \\
\text { legislation }\end{array}$ & 2013 and amended in March 2016. \\
\hline $\begin{array}{l}\text { Name of the } \\
\text { supervisor }\end{array}$ & FCA \\
\hline $\begin{array}{l}\text { Type of loan/debt } \\
\text { security }\end{array}$ & $\begin{array}{l}\text { Consumer and business loans. Consumer loans are generally regulated under the Consumer Credit } \\
\text { Act } 1974 \text { ("CCA"). In addition, some business lending is regulated, where the borrower is a sole } \\
\text { trader, a small partnership ( } 2-3 \text { partners) or an unincorporated body, and the credit does not exceed } \\
£ 25,000 \text {. Loans to companies and other bodies corporate are not regulated. }\end{array}$ \\
\hline $\begin{array}{l}\text { Minimum capital } \\
\text { requirements }\end{array}$ & $\begin{array}{l}€ 50,000 \text { or a percentage of loaned funds ( } 0.2 \% \text { of the first } £ 50 \text { million of that total value, } 0.15 \% \text { of the } \\
\text { next } £ 200 \text { million of that total value, } 0.1 \% \text { of the next } £ 250 \text { million of that total value and } 0.05 \% \text { of any } \\
\text { remaining total value) whichever is higher }\end{array}$ \\
\hline $\begin{array}{l}\text { Automatic lending } \\
\text { allowed? }\end{array}$ & Yes \\
\hline $\begin{array}{l}\text { Secondary market } \\
\text { allowed? }\end{array}$ & $\begin{array}{l}\text { Yes. In } 2016 \text { the UK Government amended Article } 36 \mathrm{H} \text { to bring peer-to-peer platform's secondary } \\
\text { markets into the scope of regulation. }\end{array}$ \\
\hline Clients' money & $\begin{array}{l}\text { Platforms can accept clients' money, but only if they hold the right regulatory permissions to do so. In } \\
\text { this case, they must ensure that client money is kept separate from the platform's own funds. }\end{array}$ \\
\hline $\begin{array}{l}\text { Provision fund } \\
\text { allowed? }\end{array}$ & Yes \\
\hline Max size of loan & $\begin{array}{l}\text { No limit. However, offers of securities to the public of over } 5 \text { million euros are required to produce a } \\
\text { prospectus by the Prospectus Directive and so, in practice, } 5 \text { million euros is the maximum amount } \\
\text { that is raised. }\end{array}$ \\
\hline $\begin{array}{l}\text { Max invested } \\
\text { amount }\end{array}$ & No limit \\
\hline $\begin{array}{l}\text { Scoring model } \\
\text { verified by the } \\
\text { regulator }\end{array}$ & No \\
\hline Collateral allowed & Yes \\
\hline $\begin{array}{l}\text { Access to credit } \\
\text { information sharing } \\
\text { scheme allowed? }\end{array}$ & $\begin{array}{l}\text { Yes. It is anticipated that peer-to-peer platforms will also benefit from the recently launched } \\
\text { Commercial Credit data sharing scheme. }\end{array}$ \\
\hline $\begin{array}{l}\text { Disclosure and risk } \\
\text { warnings }\end{array}$ & $\begin{array}{l}\text { The FCA's main disclosure requirements are contained within COBS } 6 \text { and COBS } 14 \text {. } \\
\text { https://www.handbook.fca.org.uk/handbook/COBS/6.pdf and } \\
\text { https://www.handbook.fca.org.uk/handbook/COBS/14.pdf } \\
\text { FCA rules require firms to publish their actual and expected default rates, but no exact formula is } \\
\text { provided. } \\
\text { Members of the Peer-to-Peer Finance Association (P2PFA), the industry representative body, also } \\
\text { publish their loan book. }\end{array}$ \\
\hline $\begin{array}{l}\text { Do lenders have to } \\
\text { pass a financial } \\
\text { literacy test? }\end{array}$ & No \\
\hline $\begin{array}{l}\text { Business continuity } \\
\text { requirements }\end{array}$ & Yes \\
\hline $\begin{array}{l}\text { Can platforms } \\
\text { invest in } \\
\text { loans/securities } \\
\text { that they facilitate? }\end{array}$ & $\begin{array}{l}\text { Yes - it is possible to operate this business model under the current regulations. But platforms need } \\
\text { to consider conflicts of interests that may arise. }\end{array}$ \\
\hline $\begin{array}{l}\text { Authorization of } \\
\text { platforms and } \\
\text { professional }\end{array}$ & $\begin{array}{l}\text { Applying firms must demonstrate that they meet the FCA's Threshold Conditions: Location of offices - } \\
\text { a firm must be carrying out its activities in the United Kingdom; Effective Supervision - the firm must } \\
\text { be capable of being effectively supervised by the FCA; Appropriate Resources - a firm must have } \\
\text { appropriate financial and non-financial resources (e.g. suitably qualified staff) to carry out the }\end{array}$ \\
\hline
\end{tabular}


requirements for activities for which it is applying; Suitability - the firm, and staff at the firm, must be fit and proper to applicants carry out the activities for which they are applying; Business Model - the business model of the firm must be appropriate to the activities it intends to carry on.

Firms also need to have Approved Persons for specified roles (such as directors and senior staff).

People who wish to become Approved Persons must demonstrate that they are fit and proper to hold their positions. The following aspects are taken into account when assessing these individuals: honesty, integrity and reputation; Competence and capability; Financial soundness 


\section{B. REGULATION OF LENDING-BASED CROWDFUNDING IN THE EUROPEAN UNION}

\begin{tabular}{|c|c|}
\hline & European Union \\
\hline $\begin{array}{l}\text { Legal status for } \\
\text { lending-based } \\
\text { crowdfunding } \\
\text { platforms }\end{array}$ & $\begin{array}{l}\text { The European Parliament and the Council have proposed a regulation of the European } \\
\text { Crowdfunding Service Providers for Businesses that covers both lending-based and investment- } \\
\text { based crowdfunding. 'Crowdfunding service' means includes (i) the facilitation of granting of loans; } \\
\text { (ii) the placing without firm commitment of transferable securities. }\end{array}$ \\
\hline Date of the legislation & Proposal was published in March 2018 \\
\hline $\begin{array}{l}\text { Name of the } \\
\text { supervisor }\end{array}$ & ESMA \\
\hline $\begin{array}{l}\text { Type of loan/debt } \\
\text { security }\end{array}$ & $\begin{array}{l}\text { Business lending or securities. Crowdfunding services in relation to lending to consumers does not } \\
\text { fall within the scope of this regulation. }\end{array}$ \\
\hline $\begin{array}{l}\text { Minimum capital } \\
\text { requirements }\end{array}$ & Not mentioned \\
\hline Automatic investing & Not mentioned \\
\hline Secondary market & $\begin{array}{l}\text { There is no trading system but regulation proposes a bulletin board that allows investors to interact } \\
\text { directly with each other to buy and sell loan agreements or transferable securities which were } \\
\text { originally crowdfunded on their platforms. The crowdfunding platform should inform their clients } \\
\text { that they do not operate a trading system and that such buying and selling activity on their } \\
\text { platforms is at the client's own discretion and responsibility. }\end{array}$ \\
\hline Clients' money & $\begin{array}{l}\text { Crowdfunding service providers shall not hold clients' funds or provide payment services unless } \\
\text { those funds are intended for the provision of payment services related to the crowdfunding } \\
\text { services and the crowdfunding service provider is a payment service provider as defined in Article } \\
4(11) \text { of Directive (EU) } 2015 / 2366 \text {. }\end{array}$ \\
\hline $\begin{array}{l}\text { Max size of } \\
\text { loan/security }\end{array}$ & EUR 1000000 \\
\hline Max invested amount & Not mentioned \\
\hline $\begin{array}{l}\text { Disclosure and } \\
\text { warnings }\end{array}$ & $\begin{array}{l}\text { All information, including marketing communications about the costs and charges related to } \\
\text { crowdfunding services or investments, about the crowdfunding conditions, including crowdfunding } \\
\text { project selection criteria, or about the nature of and risks associated with their crowdfunding } \\
\text { services should be clear, comprehensible, complete and correct. } \\
\text { Crowdfunding service providers should provide prospective investors with a key investment } \\
\text { information sheet drawn up by the project owner for each crowdfunding offer. }\end{array}$ \\
\hline $\begin{array}{l}\text { Access to credit } \\
\text { information sharing } \\
\text { scheme allowed? }\end{array}$ & Not mentioned \\
\hline $\begin{array}{l}\text { Do investors have to } \\
\text { pass a financial } \\
\text { literacy test? }\end{array}$ & $\begin{array}{l}\text { Yes. If crowdfunding service providers consider that the prospective investors have insufficient } \\
\text { knowledge, crowdfunding service providers should inform those prospective investors that the } \\
\text { services offered on their platforms may be inappropriate for them and give them a risk warning. } \\
\text { This risk warning shall not prevent prospective investors from investing in crowdfunding projects. } \\
\text { Crowdfunding service providers should offer investors the possibility to simulate their ability to bear } \\
\text { loss, calculated as } 10 \% \text { of their net worth. }\end{array}$ \\
\hline $\begin{array}{l}\text { Business continuity } \\
\text { requirements }\end{array}$ & $\begin{array}{l}\text { Should be described during the application for the authorization, but no details are provided in the } \\
\text { proposal. }\end{array}$ \\
\hline $\begin{array}{l}\text { Can platforms invest } \\
\text { in loans/securities that } \\
\text { they facilitate? }\end{array}$ & $\begin{array}{l}\text { Crowdfunding service providers should be prevented from having any financial participation in the } \\
\text { crowdfunding offers on their crowdfunding platforms. }\end{array}$ \\
\hline
\end{tabular}


Authorization and professional requirements
Application should contain (a) the address of the prospective crowdfunding service provider; (b) the legal status of the prospective crowdfunding service provider; (c) the articles of association of the prospective crowdfunding service provider; (d) a programme of operations setting out the types of crowdfunding services that the prospective crowd funding service provider wishes to provide; (e) a description of the prospective crowdfunding service provider's governance arrangements and internal control mechanisms to ensure compliance with this Regulation, including risk management and accounting procedures; $(\mathrm{f})$ a description of the prospective crowdfunding service provider's systems, resources and procedures for the control and safeguarding of the data processing systems; $(\mathrm{g})$ a description of the prospective crowdfunding service provider's business continuity arrangements; $(\mathrm{h})$ the identity of the persons responsible for the management of the prospective crowdfunding service provider; (i) proof that the persons referred to in point ( $h$ ) are of good repute and possess appropriate knowledge and experience to manage the prospective crowdfunding service provider; (j) a description of the internal rules of the prospective crowdfunding service provider to prevent that its shareholders who hold $20 \%$ or more of the share capital or voting rights, its managers or its employees or any person directly or indirectly linked to them by control engage in crowdfunding transactions offered by the prospective crowdfunding service provider; $(\mathrm{k})$ a description of the prospective crowdfunding service provider's outsourcing arrangements; (I) a description of the prospective crowdfunding service provider's procedures to deal with complaints from clients; $(m)$ where applicable, a description of the payment services that the prospective crowdfunding service provider intends to provide under Directive (EU) 2015/2366.

ESMA shall, within two months from the receipt of a complete application, assess whether the prospective crowdfunding service provider complies with the requirements set out in this Regulation and shall adopt a fully reasoned decision granting or refusing authorisation as a crowdfunding service provider. 